\title{
The Spectrum of Ore Deposit Types, Volcanic Environments, Alteration Halos, and Related Exploration Vectors in Submarine Volcanic Successions: Some Examples from Australia
}

\author{
Ross R. Large, ${ }^{\dagger}$ Jocelyn McPhie, J. Bruce Gemmell, Walter Herrmann, and Garry J. Davidson \\ Centre for Ore Deposit Research, School of Earth Sciences, University of Tasmania, GPO Box 252-79, Hobart, Tasmania, Australia
}

\begin{abstract}
Variations in shape, metal content, alteration mineralogy, and volcanic host rocks of the ore deposits in the two major volcanic-hosted massive sulfide (VHMS) districts of eastern Anstralia, the Canibrian Mount Read Volcanics and the Cambro-Ordovician Mount Windsor snbprovince, strongly reflect their volcanic environ. ment, conditions of ore formation, and hydrothermal alteration processes.

Lens and sheet-style polymetallic zinc-rich deposits such as Rosebery, Hellyer, Qne River, and Thalanga are considered to have formed in moderate to relatively deep water environments $(500-1,000+m)$. These deposits probably formed either on the sea floor (e.g., Hellyer, Que River) or by replacement of porous volcaniclastic units directly below the sea floor (e.g., Rosebery). The footwall alteration associated with these polymetallic VHMS deposits was controlled by host-rock permeability and porosity, which are in tum related to volcanic facies type, degree of fractnring, and synvolcanic structural architecture. Focusing of hydrothermal fluids along synvolcanic structures has resulted in well-zoned chlorite-sericite footwall alteration pipes within footwall lavas at Hellyer. On the other hand, diffnse fluid flow through very thick pninice breccia at Rosebery and Hercules has resulted in strata-bound, sericite-dominated footwall alteration zones parallel to the paleosea floor and the ore lenses.

Massive and disseminated, pyritic Cu-Au deposits, such as those in the Mount Lyell field and at HighwayReward, formed by subsea-floor replacement and are associated with only minor zinc-lead massive sulfide ore. These deposits formed from higher temperature fluids $\left(>300^{\circ} \mathrm{C}\right)$, in which copper transport is enhanced, and are commonly located in felsic volcanic centers domniated by shallow porphyritic intrusions (e.g., HighwayReward). The Cn-An ore lenses may be strata-bound (e.g., Mount Lyell) or crosscutting pipes (e.g., HighwayReward) depending on the structure and permeability characteristics of the felsic volcanic host rocks. The pres. ence of high-sulfidation alteration minerals (e.g., pyrophyllite, zunyite) in some of the Cu-An deposits (e.g., Mount Lyell field) indicates that fluids were relatively acidic and snggests the possibility of magmatic fluid input into the hydrothenmal system. Alteration zonation associated with the Cu-An VHMS deposits is more synmetrical than that of the Zn-rich deposits, with sericite-rich alteration extending into the hanging wall, in keeping with the subsnrface replacement origin of these deposits.

Synvolcanic gold-rich deposits, with high gold/base metal ratios are less common than the $\mathrm{Cu}-\mathrm{Au}$ and $\mathrm{Zn}$ rich VHMS ore types. The gold-rich ores (e.g., Henty, South Hercules) are strata bonnd in nature, have low sulfide contents, and are associated with central zones of intense silicification, surrounded by envelopes of sericite-pyrite and carbonate alteration. Volcanological and geochemical studies at Henty indicate the gold-rich ore formed by the replacement of particular volcanic units deposited in a relatively shallow water environment dominated by volcaniclastic facies, lavas, and limestones.

This spectrun of $\mathrm{Cu}-\mathrm{Au}, \mathrm{Zn}-\mathrm{rich}$, and Au-only deposits in the Mount Read Volcanics and the Mount Windsor subprovince is interpreted to represent a continunin from classic sea-floor VHMS ores toward those with features more akin to porphyry $\mathrm{Cu}-\mathrm{Au}$ and epithermal An-Ag deposits. This spectrum relates to the interplay between factors in the snbmarine volcanic environment and the character of the hydrothermal fluid as follows: (1) proportions of volcaniclastic, lava, and subvolcanic intrusive facies; (2) depth of seawater; (3) permeability and porosity of volcanic host rocks; (4) balance between magmatic components and seawater components in the ore fluid; and (5) temperature and acidity of the ore fluid.

Mineralogical, lithogeochemical, and isotopic studies have revealed a range of alteration vectors usefnl in exploration for both the $\mathrm{Zn}$-rich and $\mathrm{Cu}$-An VHMS deposits. Carbonate and white mica compositional variations are highlighted as important mineralogical vectors; thallium and antimony halos may be nseful trace element vectors; and oxygen and sulfur provide important isotope vectors toward the center of the hydrothermal system.
\end{abstract}

\section{Introduction}

THE TWO principal submarine volcanic successions in Australia that host volcanic-hosted massive sulfide (VHMS) deposits, the Cambrian Mount Read Volcanics in Tasmania and the Cambro-Ordovician Mount Windsor subprovince in

${ }^{\dagger}$ Corresponding author: e-mail, Ross.Large@utas.edu.au
Queensland, contain a range of base metal and gold-bearing sulfide deposits (Table 1). The aims of this paper are to briefly review the geological features, volcanic environments, and genesis of the spectrum of deposit styles and, based on the contributions to this special issue, to compare their patterns of hydrothermal alteration. From this analysis we propose a series of alteration vectors useful for mineral exploration. 


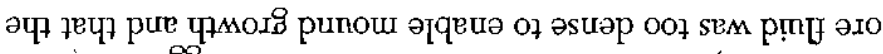

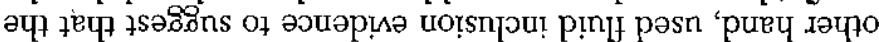

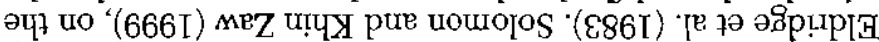

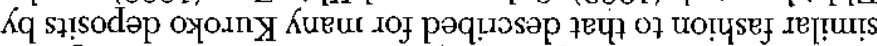

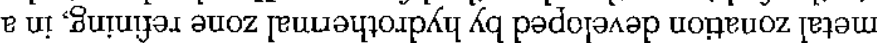

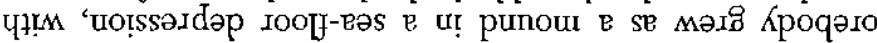

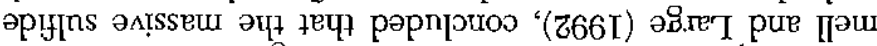

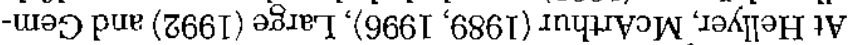

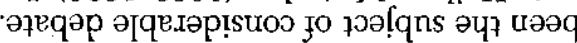

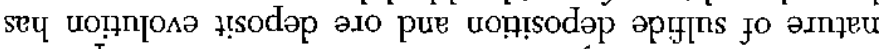

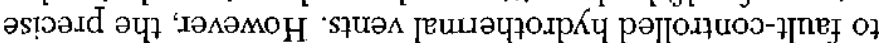
quәวе!pe suiseq II

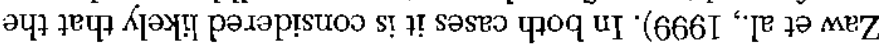

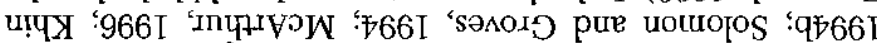

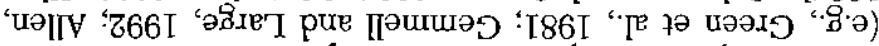

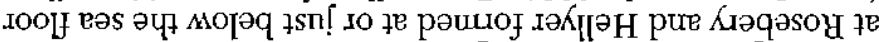

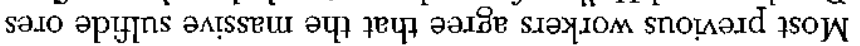

quәquoo ә

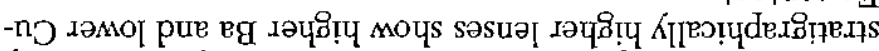

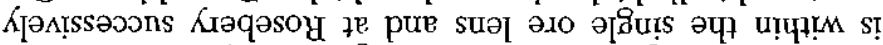

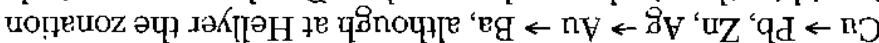

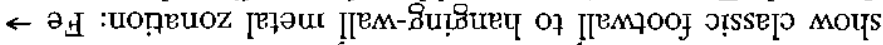

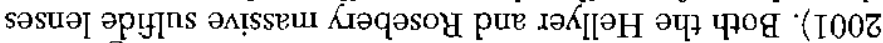

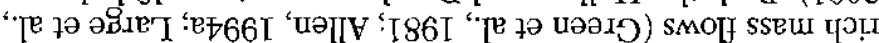

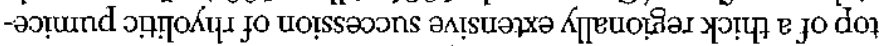

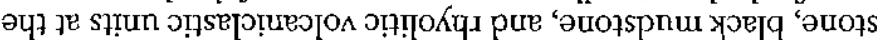

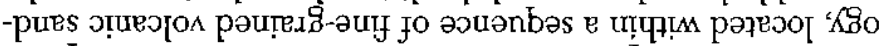

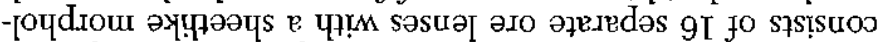

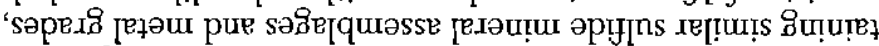
-uoo ц g

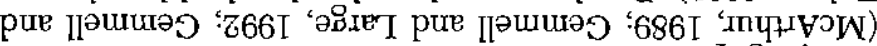

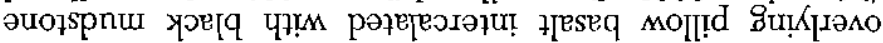

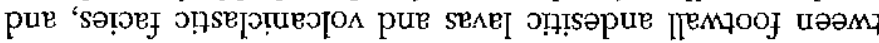

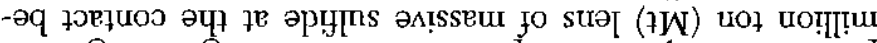

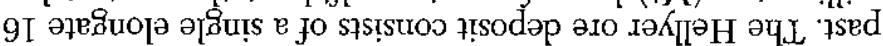

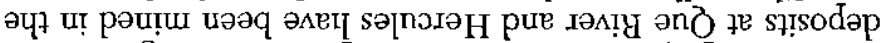

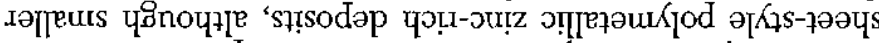

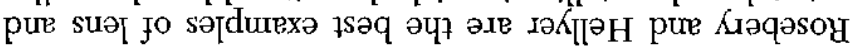

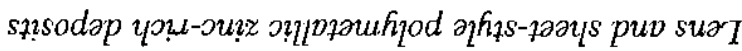

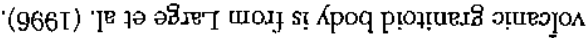

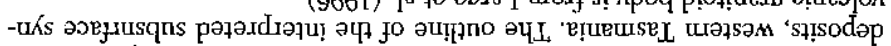

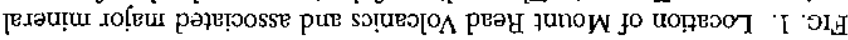

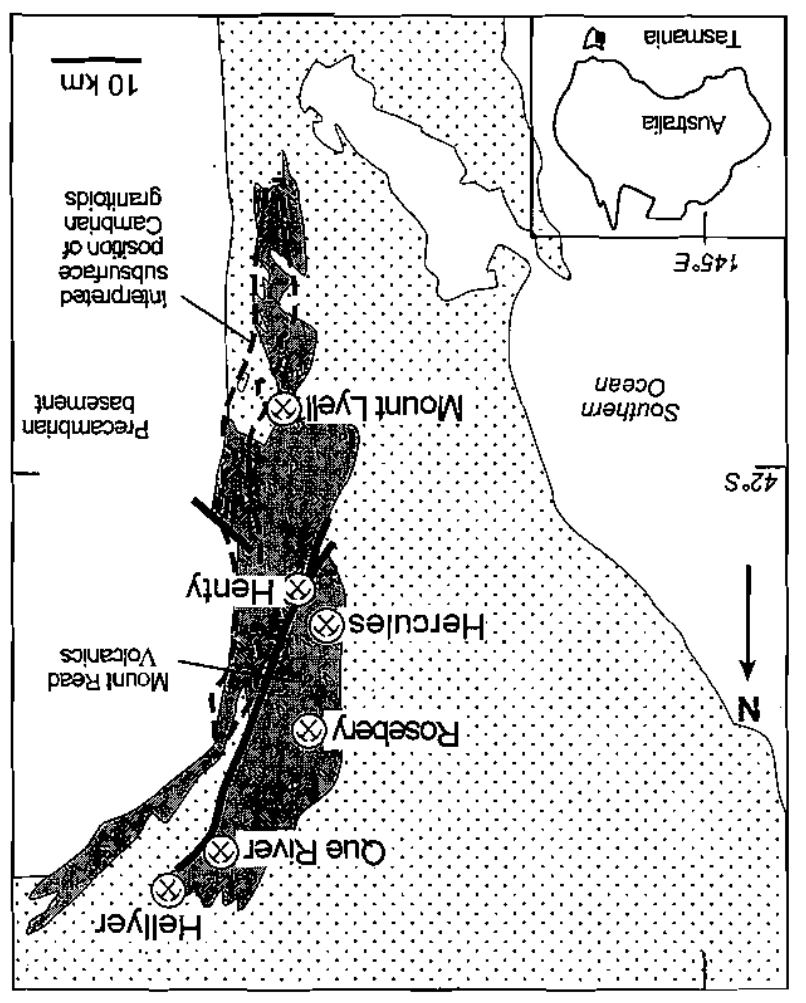

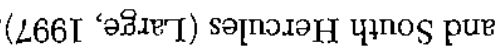

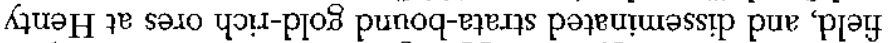

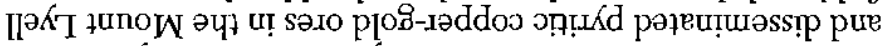

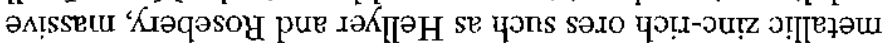

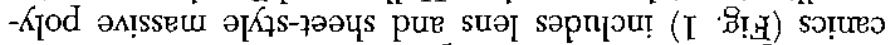

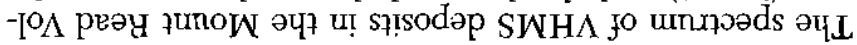
So!̣üjo $\Lambda$ pred funow

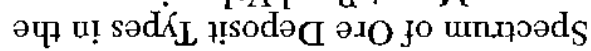

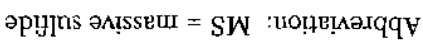

\begin{tabular}{|c|c|c|c|c|c|c|c|c|c|}
\hline 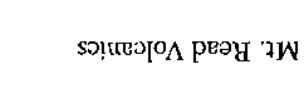 & 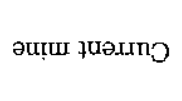 & 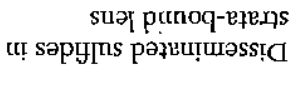 & E.TI & & & & & $L \mathrm{~L}$ & 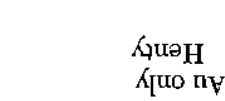 \\
\hline әəuب̣ordqus sospu!M $7 \mathbf{W}$ & 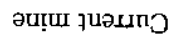 & səd!̣d s!ł! & $\mathrm{S}^{\prime} \mathrm{I}$ & & 8.9 & & & $\llcorner\mathcal{\varepsilon}$ & 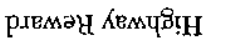 \\
\hline sэฺุueว ${ }^{\circ} \Lambda$ реәу ' $7 \mathbf{W}$ & әแฺщ ךuә..nว & 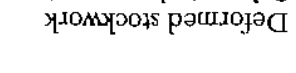 & $\varepsilon^{\circ} 0$ & & $\Upsilon$ & & & бIE & 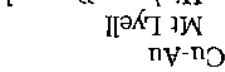 \\
\hline әоцияолdqus Iоspum $7 \mathrm{~W}$ & padsor & 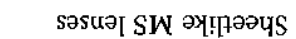 & 60 & 68 & 90 & $z z$ & $\pi 99$ & $8^{\circ} \mathrm{T}$ & имоұшо!' \\
\hline 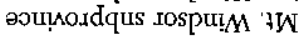 & sasnpord tsed & səsuจ SW әশ!ฺ & $\pi^{\circ} 0$ & 69 & $8^{\circ} \mathrm{T}$ & 96 & $\$ 8$ & 99 & เภิue|"บบ, \\
\hline 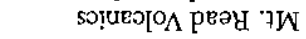 & rasnpord jsed & səsuอ SW ə]d & $8 \%$ & $69 \mathrm{~T}$ & 50 & $7 \cdot 9$ & $\varepsilon \angle \mathrm{L}$ & $\neg \varepsilon$ & sәрпวән \\
\hline 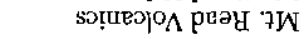 & 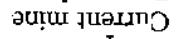 & słәәчs sw әेdn[nw & $\varepsilon z$ & $9 \mp[$ & 90 & $7 \approx$ & $\varepsilon T$ & $L^{\prime}[\varepsilon$ & Кrəqəsoy \\
\hline 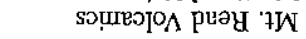 & səonpord jsed & suər SW pəplog & $\nabla^{\circ} \varepsilon$ & $00 Z$ & 90 & 92 & $9^{\circ} 8 \mathrm{I}$ & {$\left[{ }^{\circ} \varepsilon\right.$} & 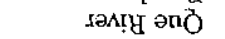 \\
\hline sộeग & рәsор әити & 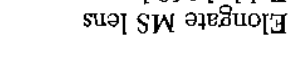 & $\varepsilon$ & O9I & \pm 0 & 1 & ET & $\pi 95$ & 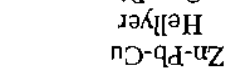 \\
\hline บоฺุองก' & srųezs & $\mathrm{WHOH}_{\mathrm{H}}$ & $\begin{array}{c}\text { (udd) } \\
\text { nV }\end{array}$ & $\begin{array}{l}\text { (udd) } \\
\text { Bv }\end{array}$ & $\begin{array}{c}(\%+M) \\
\text { no }\end{array}$ & $\begin{array}{c}(\%+M) \\
9 d\end{array}$ & $\begin{array}{c}(\%+x) \\
u_{Z}\end{array}$ & 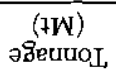 & әdূ́ 7!sodəa \\
\hline
\end{tabular}


metal sulfides precipitated within a brine poól ponded within a sea-floor depression. A potential problem with the brine pool model for Hellyer is the source of the high-salinity ore fluids. Solomon and Groves (2000) point out the lack of evidence for evaporitic sediments in the Cambrian and Precambrian basement source region and conclude that the most likely reason for the high salinities is the presence of significant magmatic fluid iuput, as previously suggested by Khin Zaw et al. (1996). However, no other evidence exists for the involvement of magnatic fluids at Hellyer.

Solomon and Walshe (1979) and Solomon and Groves (1994) considered that the sheetlike form, stratiform sulfide banding, large size, and high $\mathrm{Zn}-\mathrm{Pb}$ metal content of the Rosebery deposit set it apart from the classical mound-style Kuroko massive sulfide deposits. They argue that Rosebery is more hike the large VHMS deposits in the Bathurst district, Canada, than the smaller Kuroko deposits of Japan. In some respects Rosebery could be considered to possess some of the features of a SEDEX deposit (e.g., banded sheetlike form, high $\mathrm{Zn} / \mathrm{Cu}$ ratio, high tonnage, lack of a well-developed stringer zone) located within a volcanic rather than a sedimentary setting.

Solomon and Groves (1994) proposed that Rosebery and similar sheetlike, banded, large tonnage and/or grade VHMS deposits formed within a brine pool from relatively high salinity fluids that nnderwent reverse buoyancy on mixing with seawater. In marked contrast to this model, Allen (1994a, b) provided volcanological and textural evidence to suggest that the sheetlike form and mineral banding in some of the Rosebery ore lenses are due to subsea-floor replacement of pumice-rich units below impermeable quartz-porphyritic rhyodacitic synvolcanic sills. A similar process of subsea-floor replacement was also proposed by Khin Zaw and Large (1992) for the South Hercules deposit, situated to the south of Rosebery.

In snmmary, the jury is still out on the exact process of the formation of Rosebery and Hellyer, but most workers agree that the ores are synvolcanic and formed on, or just below, the sea floor, from moderate- to high-salimity ore fluids (5-15 wt $\% \mathrm{NaCl}$ and $160^{\circ}-320^{\circ} \mathrm{C}$; Khin Zaw et al., 1996).

\section{Massive and disseminated strata-bound. pyritic Cu-Au deposits}

The Mount Lyell district (Fig. 1) contains $22 \mathrm{Cu}-\mathrm{Au} \mathrm{de}$ posits witl a total of $312 \mathrm{Mt}$ of 1.0 percent $\mathrm{Cu}$ and $0.3 \mathrm{~g} / \mathrm{t} \mathrm{Au}$ hosted within rhyolitic and dacitic volcanic facies. Previous studies (e.g., Cox, 1981; Walshe and Solomon, 1981; Large, 1992) considered the $\mathrm{Cu}-\mathrm{Au}$ deposits to be largely subseafloor replacement VHMS ores; however, recent research (Corbett, 2001; Huston and Kamprad, 2001) has demonstrated that the ores have mineralogical and alteration affinities with high-sulfidatiou epithermal deposits and may thus represent a hybrid type between VHMS and epithermal deposits, developed within a submarine volcanic successsion. There is disagreement on the timiug of the $\mathrm{Cu}-\mathrm{Au}$ mineralization and high-sulfidation alteration event. Huston and Kampred (200I) argue for an Ordovician age for the mineralization and alteration ( $\sim 460 \mathrm{Ma}$ ), whereas Corbett (2001) provides convincing evidence for a Cambrian age similar to other deposits in the Mount Read Volcanics. Corbett (2001, fig. 3) has recogmized a zonation throughout the Mount Lyell district, from large disseminated pyrite-chalcopyrite ores at depth (with elevated magnetite-apatite-REE), passing upward to bornite-rich ores in a zone of intense massive and vuggy sihca alteration (including enargite and pyrophyllite) below the paleosea floor, followed by an uppermost zone of small, massive sulfide $\mathrm{Zn}-\mathrm{Pb}-\mathrm{Cu}$ lenses interpreted as exhalative sea-floor deposits.

Subvolcanic intrusions in the Mount Lyell district: A series of granitic sill-hke intrusions occur at depth along the eastern margin of the Mount Read Volcanics (Fig. 1). Research by Mike Solomon and his students (Solomon, 1976; Polya et al., 1986; Eastoe et al., 1987) proposed a relationship between synvolcanic granite emplacement, district-scale alteration, seawater circulation, and massive sulfide formation. More recently, Large et al. (1996) suggested the possibility of a direct imput of magnatic fluids carrying gold, copper, iron, and phosphorous to form the copper-gold VHMS deposits in the Mount Lyell district. Geophysical evidence (magnetics and gravity) indicates that the granite(s) form a narrow discontinuous body or series of bodies about $60 \mathrm{~km}$ long and 2 to $4 \mathrm{~km}$ wide toward the base and eastern margin of the volcanic pile that hosts the deposits (Large et al., 1996, fig 4). The two outcropping parts of the elongate composite granite body (the Murchison and Darwin granites) are strongly altered, high $\mathrm{K}$, magnetite series granites. The Murchison granite varies in composition from diorite to granite (58-78 wt $\% \mathrm{~S}_{2} \mathrm{O}_{2}$; Polya et al., 1986), whereas the Darwin granite is composed of two highly fractionated phases (Jones, 1993) with an $\mathrm{SiO}_{2}$ content from 74 to 78 wt percent. The depth of the granite below the lowest VHMS horizon is difficult to determine due to later structural events. Various reconstructions place the granites at a depth of 3 to $7 \mathrm{~km}$ below the ore horizon.

The coeval and comagmatic nature of the granites and volcanics is based on geology (Polya et al., 1986; Corbett, 1992; Jones, 1993), geochemistry (Crawford et al., 1992; Wyman, 2000), and geochronology (Perkins and Walshe, 1993). Radiometric dating gives an age of $508 \pm 6$ Ma compared to the range of the Mount Read Volcanics of 501 to $510 \pm 7 \mathrm{Ma}$ (Perkins and Walshe, 1993). The dating is not sufficiently precise to establish the exact timing of the Cambrian granite intrusion with respect to $\mathrm{Cu}-\mathrm{Au}$ mineralization at Mount Lyell.

Based on regional alteration studies, complimented by gravity and magnetic patterns, Large et al. (1996) suggested that the Mount Lyell hydrothermal alteration system was connected to a deep-seated magmatic-hydrothermal alteration system related to the elongate Cambrian granite(s) that crop out south of Mount Lyell in the Jukes and Darwin areas. Lowgrade porphyry Cu-style mineralization has been recognized in places surrounding the Cambrian granites (Hunns, 1987; Doyle, 1990, Large et al., 1996), where it is associated with magnetite-chlorite and tourmaline-quartz veins that overprint early K feldspar alteration (Wyman, 2000).

Convincing evidence for magmatic fluid and metal input into the hydrothermal system at Mount Lyell is difficult to document, probably because the system has been swamped by seawater convection over the life of the hydrothemal cell. However, evidence in favor of the Cambrian granites acting as a thermal source and contributing a magmatic component to the ore fluid includes (see also Solomon and Groves, 2000): 
(I) the whole-rock and trace element geochenistry indicates the granitoids are comagmatic with the suite I volcanics that host and underlie most of the deposits (Crawford, et al. 1992); (2) the preseuce of alteration minerals (e.g., pyrophyllite, allumite types) adjacent to the ores indicates a very acidic hydrothermal fluid (Huston and Kamprad, 2001); (3) the presence of magnetite-apatite \pm pyrite assemblages at Prince Lyell aud a correlation between $\mathrm{Cu}, \mathrm{P}$, and $\mathrm{Fe}$ in the ores (Large et al., 1996); (4) the $\mathrm{O}^{18}$-enriched hydrothermal magnetite of about 4 per mil at Prince Lyell indicates a magmatic origin (Raymond, 1992); (5) the $\mathrm{Nd}-\mathrm{Sm}$ isotope data support a link between apatites in the magnetite-apatite assemblages at Priuce Lyell and the Cambrian granites (Wyman, 2000); (6) the recent fluid inclusion studies by Khin Zaw et al.(in press) in the Western Tharsis deposit, Mt. Lyell, indicate salinities much higher than seawater - $m$ the range 6 to $34 \mathrm{wt}$ percent $\mathrm{NaCl}$; and (7) the high $(\mathrm{Cu}+\mathrm{Au}) /(\mathrm{Zn}+\mathrm{Pb}+\mathrm{Ag})$ ratios in the ores are compatible with high-temperature, acidic ore fluids of magmatic origin.

Our current model for the Mount Lyell field (Fig. 2) depicts the major disseminated $\mathrm{Cu}-\mathrm{Au}$ ores, such as Prince Lyell and Western Tharsis, as hybrid VHMS-high-sulfidation epithernal style ores with a connection to a low-grade porphyry environment at depth (e.g., Jukes Pty. prospect) and an exhalative $\mathrm{Zn}-\mathrm{Pb}$ massive sulfide at the sea floor above (e.g., Comstock deposit $\rangle$. The formation processes and geological environment of $\mathrm{Cu}-\mathrm{Au}$ deposits in the Mount Lyell field may be similar to that suggested by Sillitoe et al. (1996, fig. 2) for high-sulfidation volcanogenic massive sulfide deposits.

\section{Disseminated strata-bound gold-rich ores}

There are several synvolcanic gold-rich deposits in the Mount Read Volcanics that coutain a high gold/base metal ratio and are composed principally of disseminated mineralization rather than massive sulfide lenses. The Henty deposit (Halley and Roberts, 1997; Callaghan, 2001), a current producing inine (1.7 Mt at $11 \mathrm{~g} / \mathrm{t} \mathrm{Au}$ ), is the best known example, but others include South Hercules (Khin Zaw and Large, 1992) and the footwall precious metal zone at Que River (McGoldrick and Large, 1992).

Henty is a low-sulfide strata-bound gold deposit within an intensely silicified zone adjacent to the regionally extensive Henty fault system. Although the deposit is synvolcanic and, based on $\mathrm{Pb}$ isotope and stratigraphic evidence (Halley and
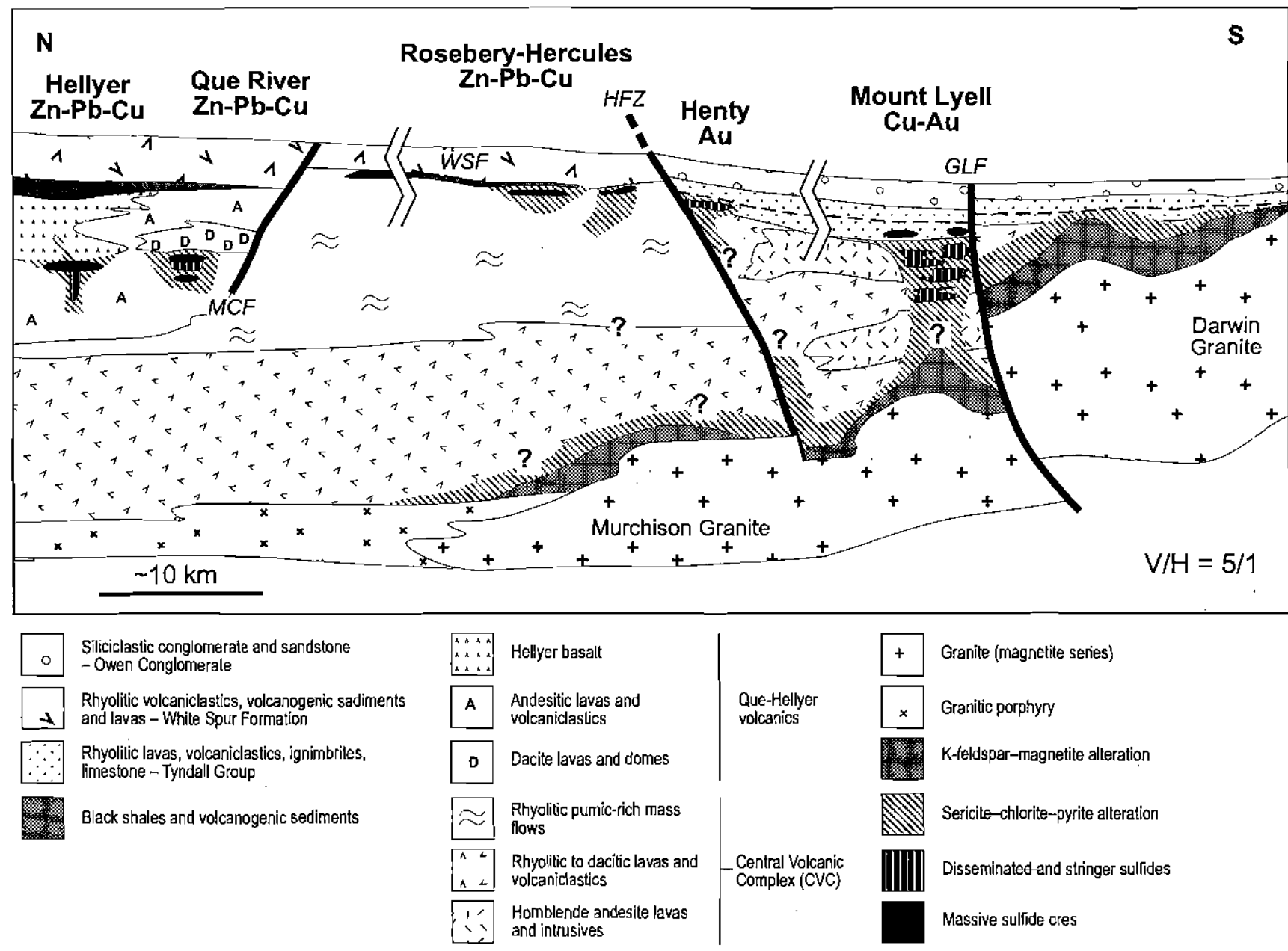

FIG. 2. Schematic long section for the Mount Read Volcanics showing the interpreted loeations and morphologies of VIIMS deposits and their associated alteration zones (based on Large et al., 1996; Halley and Roberts, 1997; Callaghan, 2001; Corhett, 2001). 
Roberts, 1997), roughly the same age as the other felsic volcanic-hosted deposits at Rosebery and Mount Lyell, features which make it significantly different from the other VHMS deposits in the belt include the following: (1) it is a low sulfide disseminated style with only minor lenses of massive polymetallic sulfide; (2) it is hosted by a relatively shallow water facies association, including ignimbrite and limestone, at the base of the Tyndall Group (White and McPhie, 1996); and (3) the gold-silver-tellurium-rich core of the deposit is surrounded by a zone of copper-lead-bismuth and an outer halo of zinc (Callaghan, 2001).

Halley and Roberts (1979) compared Henty to other goldrich massive sulfides described by Poulsen and Hannington (1995) and concluded that Henty was a shallow-water exhalative VHMS deposit with high gold and low base metal grades related to boiling of the hydrothermal fluid. Recent work by Beckton (1999) and Callaghan $(1998,2001)$ has shown that the stratabound gold ores formed by replacement rather than exhalation. Callaghan (2001) argues that the metal association (Au-Cu-Bi$\mathrm{Te}$ ), extensive carbonate alteration halo, and replacement textures suggest that the deposit fonned by subsea-floor replacement of particular volcanic and carbonate-rich units during mixing of a magmatic-hydrothermal fluid with seawater.

In most respects Henty has little in common with typical VHMS deposits, such as Hellyer and Rosebery, and is more akin to a shallow marine strata-bound epithermal Au-Ag replacement deposit (Fig. 2). Previous workers (e.g., Corbett,
1992; Callaghan, 2001) have noted that Henty and the Comstock deposits at the top of the Mount Lyell system lie at the same stratigraphic level at the base of the Tyndall Group. A number of other $\mathrm{Cu}-\mathrm{Au}$ and $\mathrm{Zn}-\mathrm{Pb}$ prospects lie at this stratigraphic position between Henty and Mount Lyell, suggesting the possibility that the gold-rich ores at Henty represent the top of a magmatic-hydrothermal system similar to the coppergold system at Mount Lyell (Fig. 2).

\section{Comparisons to deposits in the Mount Windsor subprovince:} Queensland

Three significant massive sulfide deposits (Thalanga, Highway-Reward, and Liontown) and another five small massive sulfide lenses (Waterloo, Argincourt, Magpie, Handcuff, and Warrawee) are known from the Cambro-Ordovician Mount Windsor subprovince (Fig. 3). Except for Highway-Reward, all the deposits are stratiform polymetallic ( $\mathrm{Zn}-\mathrm{Pb}-\mathrm{Cu}-\mathrm{Au}-\mathrm{Ag}$ ) massive sulfide lenses, showing some similarities to the Rosebery and Hellyer deposits in the Mount Read Volcanics. In contrast, Highway-Reward consists of several discordant massive pyritic $\mathrm{Cu}-\mathrm{Au}$ pipe-shaped bodies and has some features in common with the Mount Lyell deposits in Tasmania. For the purposes of this comparison we will discuss the characteristics and origin of the two principal deposits at Thalanga and Highway-Reward.

Thalanga deposit: Thalanga comprises several sheetlike, steeply dipping, sulfide lenses extending over about $3 \mathrm{~km}$ of

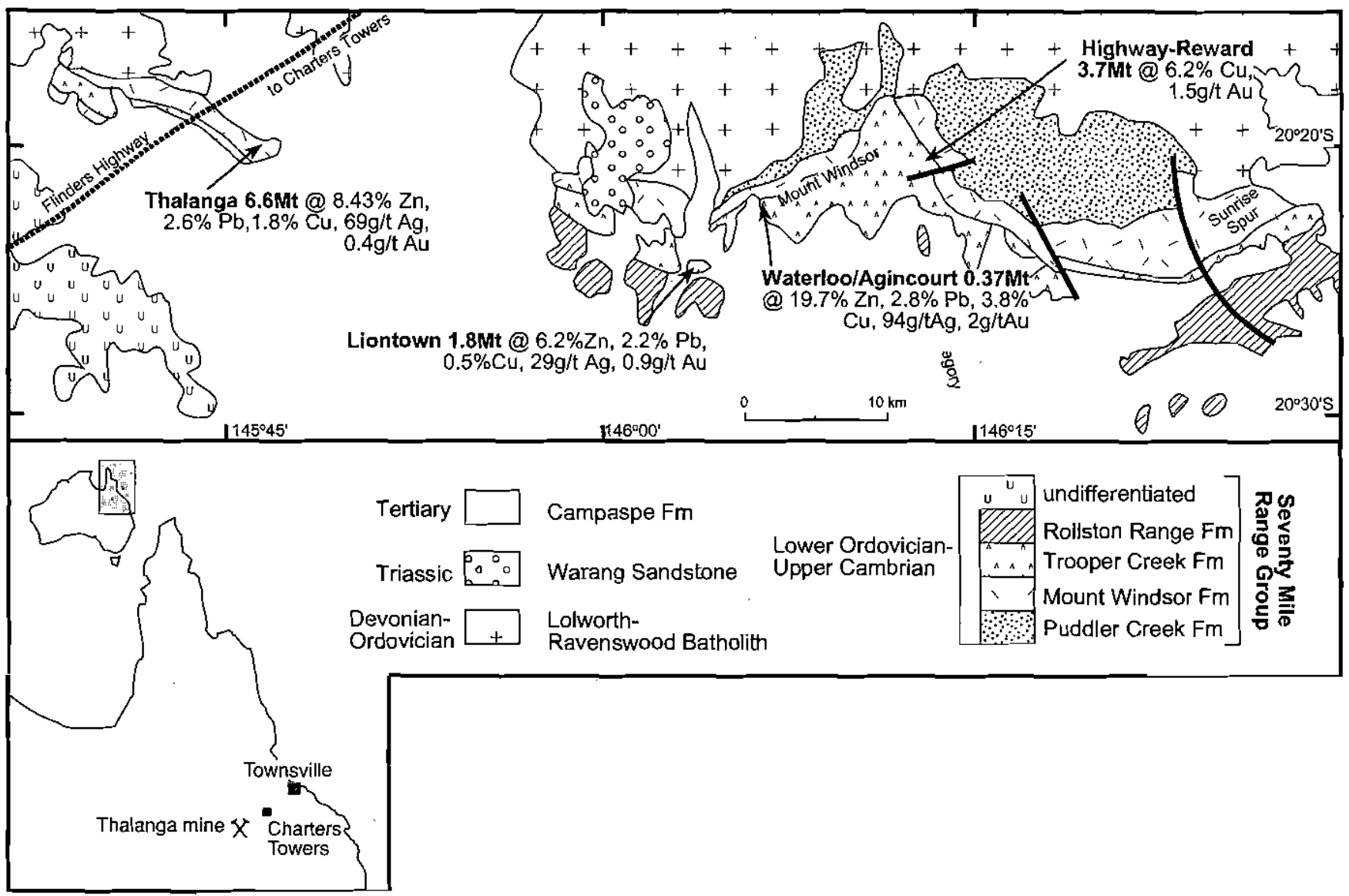

FIG. 3. Locations of VHIMS deposits in the Mount Windsor subprovince, eastern Queensland. 
strike and contaiming a total of about $7 \mathrm{Mt}$ of ore. The ore lenses are strata bound within a single stratigraphic interval that is dominated by coarsely volcaniclastic facies and sills with quartz phenocryts above a thick footwall sequence of rhyolitic lavas and intrusions and beneath a hanging-wall sequence of dacitic lavas and volcaniclastic units. The ore lenses and enclosing rocks were deformed and metamorphosed to upper greenschist-grade assemblages during the Mid-Late Ordovician period (Berry et al., 1992). Remobilization has complicated inetal zonation in the sulfide lenses, but they are generally pyritic and copper rich at the stratigraphic base and zinc-lead rich elsewhere. Semimassivc barite \pm magnelite exists in the lateral and upper fringes of some ore lenses. The sheetlike morphology and metal zonation at Thalanga are similar to that exhibited by the Rosebery deposit in the Mount Read Volcanics.

An extensive, feldspar-destructive sericite-chlorite-pyrite alteration zone stratigraphically underlies the deposit. Within this pervasive alteration zone are discrete quartz-pyrite \pm chlorite stringer zones of intense alteration that appear to represent discordant hydrothermal feeders leading obhiquely up to the sulfide lenses (Paulick et al., 2001). Thin stratabound zones of chlorite-tremolite-carbonate associated with ore in the western lenses represent metamorphosed chloritecarbonate alteration assemblages (Herrmann and Hill, 2001). Dacitic volcanic facies in the hanging wall immediately above the ore are essentially unaltered.

The deposit is interpreted to have formed in a moderate to deep marine setting, probably in sea-floor depressions on the crest of a rhyolite lava-dominated volcanic center (Paulick and McPhie, 1999). Sulfur isotope data from barite and sulfides are consistent with sulfur derivation from CambroOrdovician seawater and igneous rocks (Hill, 1996). Several lines of evidence indicate that the sulfide lenses formed directly on the sea floor and partly by replacement of volcaniclastic facies in the upper few meters of the substrate. The evidence includes: (1) the strata-bound distribution of lenses immediately above zones of intense alteration in the footwall; (2) the presence of clasts of massive sulfide in polymictic volcanic breccias; and (3) the immobile element composition of ore-related chlorite-tremolite-carbonate rocks, which indicates that these units formed by replacement of volcanic rocks (Hermann and Hill, 2001).

Highway-Reward deposit: The Highway-Reward deposit comprises three subvertical pipelike bodies of massive pyrite and minor chalcopyrite totaling about $10 \mathrm{Mt}$ and including a premining resources of $3.7 \mathrm{Mt}$ grading 6.2 percent $\mathrm{Cu}$ and 1.7g/t Au (Graig Miller, pers comınun., 2000) The massive pyrite pipes have a verlical extent of up to $250 \mathrm{~m}$, discordant with the shallowly dipping volcamic host seqnence. They are surrounded by a broad low-grade halo of sphalerite \pm galena \pm barite in disseminations and veinlets. A small strata-bound lens of sphalerite-pyrite-galena-chalcopyrite-barite exists about $50 \mathrm{~m}$ above the southern edge of the Reward pipe. The host rocks comprise numerous small (tens of meters in diameter) domelike bodies of felsic porphyritic intrusive rocks separated by intervals of volcanic siltstone, sandstone, and pumiceous and polymictic breccia (Doyle and McPhie, 2000; Doyle, 2001). Doyle and Huston (1999) concluded that the massive pyrite pipes, although essentially synvolcanic, formcd mainly by subsea-floor replacement of the permeable $\mathrm{m}$ gins of adjacent felsic cryptodomes.

\section{Spectrum of Volcanic Environments Hosting VHMS Deposits}

The Cambrian Mount Read Volcanics in western Tasma: and the Cambro-Ordovician Mount Windsor subprovince Queensland host important massive sulfide deposits that $d$ play a range of textural, mineralogical, and compositiol claracteristics. Both of these successions comprise comp. assemblages of texturally and compositionally diverse volcal facies that also illustrate a wide spectrum in the volcanic $\epsilon$ vironments of massive sulfide ore formation. Research cos bining volcanic facies analyses and alteration studies has be undertaken at Rosebery (Allen, 1994a; Large et al., 2001) a Hellyer (Waters and Wallace 1992; Gemmell and Fultc 2001) in the Mount Read Volcanics, and at Thalanga (Pauli and McPhie 1999; Paulick et al., 2001) and Highway-Rewa (Doyle and McPhie, 2000; Doyle, 2001) in the Mount Win sor subprovince. These deposits serve to demonstrate mur of the spectrum, in some cases being hosted by lavas or sy volcanic intrusions and others by volcaniclastic successior They also show marked variations in the geonetry and sty of both of the massive sulfide orebodies and related $h$ drothermal alteration halos.

In this section, the principal facies characteristics of the ho successions to these four massive sulfide deposits are summ. rized. We also briefly consider how primary facies characteri tics of the host volcamic successions, especially porosity, pe meability, and the presence of volcanic glass, have influence the distribution and texture of alteration facies. This subject examined in detail in Gifkins and Allen (2001) on Rosebery $i$ the Mount Read Volcanics and in Doyle (2001) on Highwas Reward in the Mount Windsor subprovince.

\section{Facies architecture of the Mount Read Volcanics}

The regionally mappable lithostratigraphic units within th Mount Read Volcanics each comprise a varied assemblage c volcanic facies types, in some cases together with nonvolcanic principally sedimentary facies. The principal lithostrati graphic units are the Central Volcanic Complex, Eastern quart phenocryst sequence, Western volcano-sedimentary sequence (Yolande River sequence, Dundas Group, Mount Charte Group), and the Tyndall Group (Corbett 1992). Although fel sic compositions dominate the volcanic facies of all lithos tratigraphic units, intermediate to mafic volcanic facies ar locally important, especially within the Central Volcani Complex and the Western volcano-sedimentary sequences 'The lithostratigraphic units can be mapped on the basis of the dominant facies types present and provide a framework fo. the volcanic facies architecture. Essential elements of the fa cies architecture are a volcanic facies association comprisin lavas and domes, diverse volcaniclastic facies, and synvolcanic intrusions; and a sedimentary facies association comprising black pyritic mudstone, micaceous mudstone, and basement. derived sandstone (Mc.Phie and Allen, 1992).

Lava flows and domcs consist of both coherent and autoclastic (autobreccia, hyaloclastite, resedimented hyaloclastite. and intrusive hyaloclastite) facies. Flows and domes commonly occur in associatiou with synvolcanic imtrusions, mainly sills 
and cryptodomes. Margins of the extrusions and intrusions are typically glassy and in some cases, pumiceous; formerly glassy domains are commonly perlitic. Interiors are typically microcrystalline, spherulitic, or micropoikilitic. Although the volcaniclastic facies range widely in textural characteristics, there are four particularly common types: (1) very thick (tens of meters), massive to graded beds of rhyolitic pumice breccia; (2) very thick, massive to diffusely stratified units of crystal-rich (feldspar, quartz, clinopyroxene) sandstone; (3) thick to very thick, massive to graded beds of polymictic volcanic conglomerate or breccia; and (4) pale, inassive or laminated shard-rich mudstone.

The facies architecture of the Mount Read Volcanics shows distinct regional variations in the proportions of volcanic versus sedimentary facies. The volcanic facies association locally dominates the succession, but elsewhere the volcanic facies are interbedded with, or subordinate to, sedimentary facies. For example, sections about $800 \mathrm{~m}$ thick through the Mount Read Volcanics at Mount Black near Rosebery are composed almost entirely of volcanic facies (felsic lavas, intrusions, pumice breccia), whereas at Hellyer sedimentary facies (black mudstone and inicaceous mudstone) up to $700 \mathrm{~m}$ thick dominate hanging-wall sections.

The volcanic facies association exhibits considerable diversity in eruption and emplacement processes. The spectrum ranges from the products of exclusively effusive, intrabasinal eruptions, such as the andesitic lavas and domes in the footwall of the Hellyer massive sulfide orebody, to the products of explosive eruptions, possibly from vents located at the basin margin, such as the pumice breccia units in the hanging wall at Hellyer. Among the volcaniclastic facies, there is a spectrum from facies that are clearly syneruptive, having been generated by a coeval explosive eruption, to posteruptive facies that exhibit evidence for temporary storage and reworking prior to redeposition. Syneruptive facies are characterized by the dominance of unmodified juvenile components of uniform composition and very thick, mass-flow sedimentation units. The very thick rhyolitic pumice breccia units of the footwall to the Rosebery and Hercules massive sulfide orebodies are excellent examples of syneruptive facies that record a major explosive eruption. Massive to graded beds of polymictic volcanic conglomerate with significant proportions of rounded clasts occur in the Rosebery-Hercules hanging wall and are good examples of volcaniclastic facies thought to be posteruptive, generated by more complex and lengthy transport and reworking histories.

The volcanic facies association in the Mount Read Volcamics also displays marked regional variations in the proportions of magma compositions represented. Much of the succession is dominated by rhyolite and dacite. For example, primary and syneruptive volcanic facies in the host succession to the Rosebery and Hercules massive sulfide deposits are almost exclusively rhyolitic to dacitic. However, intermediate to mafic volcanic facies are important at several locations, some of which host massive sulfide deposits. For example, at Hellyer, the volcanic facies in the footwall are mainly andesitic, facies coeval with the orebody are dacitic, and the hanging wall includes thick $(\sim 100 \mathrm{~m})$ basaltic sills.

Another aspect of the geology of the Mount Read Volcanics that shows important variation is the inferred water depth at the time of emplacement. A below wave base, moderate to relatively deep submarine setting is inferred to have prevailed for most of the succession and is indicated by the presence of trilobite and other marine fossils, turbidites, and black pyritic mudstone in the sedimentary facies association. This interpretation is consistent with the presence of very thick volcaniclastic mass-flow units, hyaloclastite, peperite, and pillow lava in the volcanic facies association. The Rosebery, Hercules, Hellyer, and Que River orebodies probably all formed in such moderate- to deep-water environments. No conclusive evidence for the exact water depth at the time of mineralization is available, but based on the lack of evidence of boiling in fluid inclusions at Hellyer and Rosebery (Khin Zaw, 1991; Khin Zaw et al., 1996) and by anology with present-day sea-floor massive sulfides, it is speculatively assumed that the depth ranged from about 500 to greater than $1,000 \mathrm{~m}$. In contrast, a shallower water setting, at or just below storm wave base, is most likely to have existed for much of the region during deposition of the youngest hithostratigraphic unit, the Tyndall Group, when the Au-rich Henty deposit and the uppermost parts of the Cu-Au Mount Lyell deposits were fonned. The evidence for a shallower setting at Henty includes the local presence of limestone that contains a shallow-water fauna and in situ welded ignimbrite (White and McPhie, 1997)

\section{Setting of Hellyer}

The Hellyer massive sulfide orebody occurs within a substantial, intermediate to mafic volcanic succession known as the Que-Hellyer Volcanics, which is part of the Mount Charter Group (Corbett and Komyshan, 1989). The inassive sulfide occurs above a footwall comprising andesitic and basaltic lava and sills with quartz phenocryts, together with associated autoclastic breccia (mainly hyaloclastite) and peperite (Wa. ters and Wallace 1992; Fig. 4a). The hanging wall is dominated by basalt (Hellyer Basalt). The abundance of basaltmudstone peperite indicates that most of the basalt units are sills that intuded black mudstone (Que River Shale). Very thick, graded units of rhyolitic pumiceous and volcanic lithic breccia interbedded with turbidites and mudstone occur in the upper parts of the hanging wall (Southwell Subgroup). Along strike from the massive sulfide, the ore position is marked by coarse polymictic volcanic breccia, sandstone, and mudstone, and dacitic lavas and domes.

Trilobites in the Que River Shale, very thick sections of black mudstone, and the abundance of graded mass-flow units collectively indicate that the Hellyer massive sulfide formed in a moderate to deep ( $>1,000 \mathrm{~m}$ ?) submarine setting. The volcanic facies association indicates proximity to intrabasinal vents for effusive basaltic and andesitic eruptions and synvolcanic intrusions.

The hydrothennal system responsible for the Hellyer massive sulfide was hosted by a lava- and intrusion-dominated volcanic succession. In such successions, permeability can be very high but is commonly fracture controlled and is also strongly influenced by facies geometry, especially the margins of lavas or domes. These controls are reflected in the well-defined and pipelike footwall alteration (Gemmell and Large, 1992) that suggests fluid flow was strongly focused by a vertical synvolcanic fault. 
a

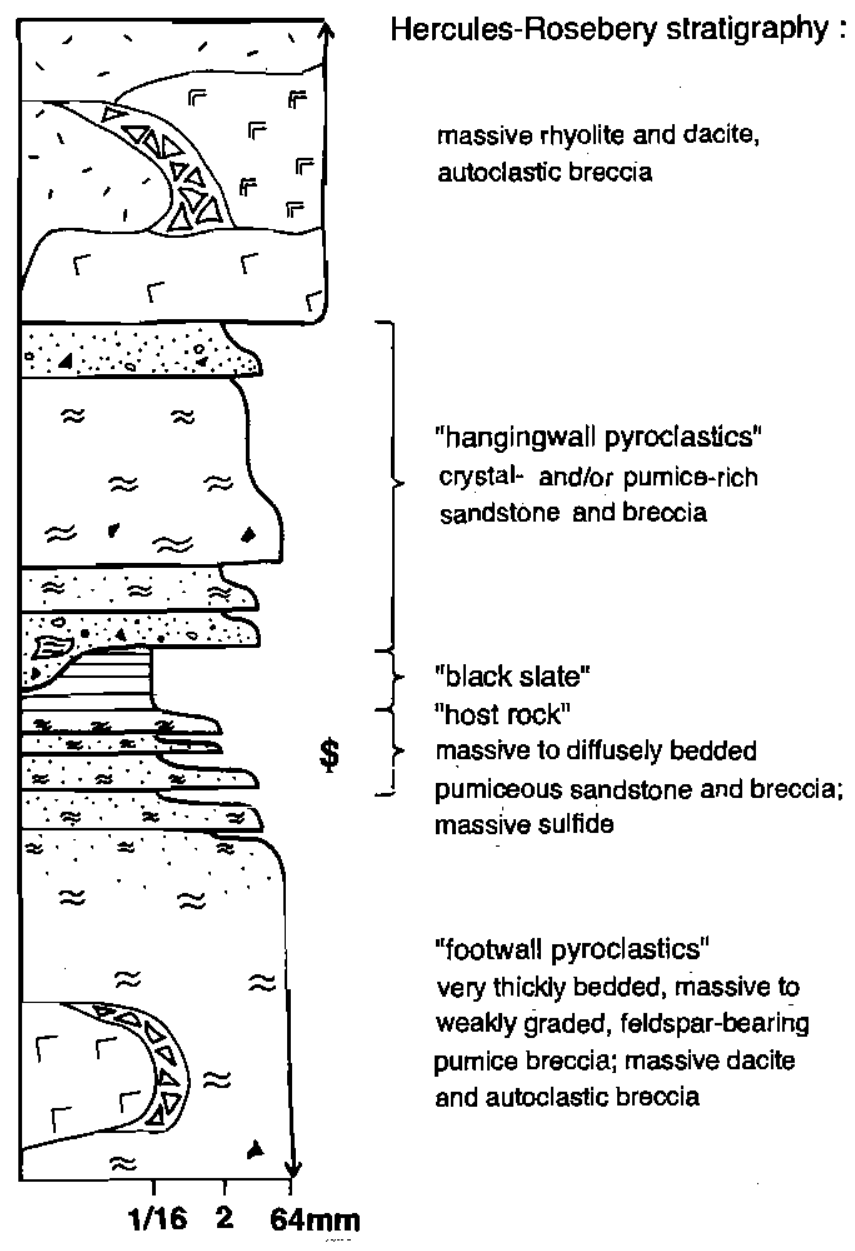

b

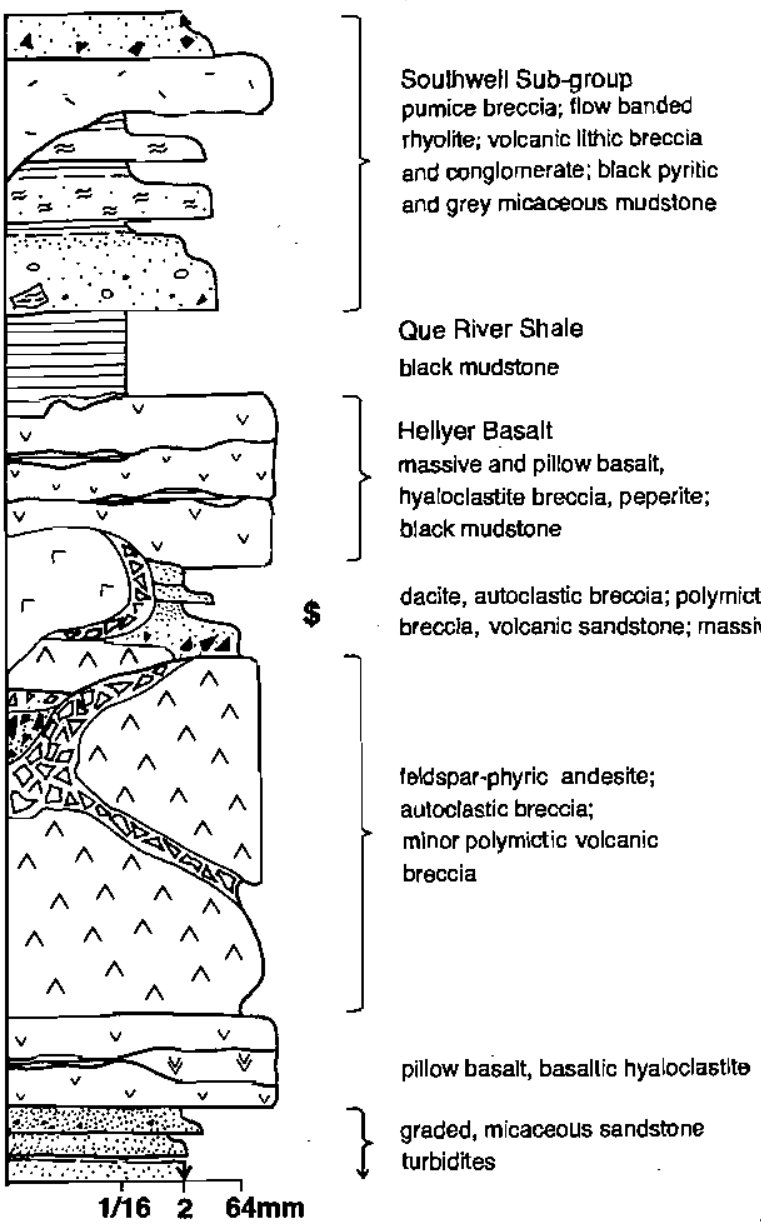

FIG. 4. Stratigraphic columns showing volcanic facies relationships in the (a) Rosebery-Hercules, and (b) Hellyer-Que River areas of the Mount Read Volcanics. The \$ sign denotes the stratigraphic position of massive sulfide deposits.

\section{Setting of Rosebery and Hercules}

The Rosebery and Hercules massive sulfide lenses occur in part of the Central Volcanic Complex that is dommated by very thick, weakly graded units of feldspar-porphyritic rhyolitic pumice breccia. The ore lenses are located in the stratified pumiceous sandstone and mudstone top (host rock, Fig. $4 \mathrm{~b}$ ) of very thick pumice breccia that forms most of the footwall (Allen, 1994a; Large et al., 2001). The hanging wall comprises thick graded beds of variably crystal-rich and pumiceous sandstone (hanging-wall pyroclastics) interbedded with black mudstone.

A below-wave base submarine setting for the RoseberyHercules successiou is clear from the presence of very thick graded beds and black mudstone, but there are no features that provide more precise constraints. The volcanic facies association is dominated by syneruptive pumiceous mass-flow deposits generated by a voluminous rhyolitic explosive eruption. The vent position has not been identified but was probably not within the area encompassed by existing exposures.

The hydrothermal system that produced the Rosebery and Hercules ore lenses operated in a volcaniclastic succession with, at least imitially, very high permeability and porosity. As a result, hydrothermal alteration of the footwall and host rocks is pervasive, widespread, conformable, and of variable intensity (Large et al., 2001). In addition, it is likely that the highly permeable host facies inhibited venting of hydrothermal fluids at the sea floor and instead favored a subsea-floor replacement origin for some of the ore lenses (Allen, 1994b).

\section{Facies architecture of the Mount Windsor subprovince}

The regional lithostratigraphy of the Mount Windsor subprovince was described by Henderson (1986) and refined by Berry et al. (1992). There are four formations: the Puddler Creek Formation at the base, the Mount Windsor Formation, the Trooper Creek Formation, and the Rollston Range Formatiou at the top (Fig 4). The middle two formations (Mt. Windsor Formation and Trooper Creek Formation) are domiuated by volcanic facies, whereas the lowest and topmost formations are dominated by sedimentary facies, principally turbidite and pelagic mudstone. The assemblage of volcanic facies is typical of submarine volcanic successions elsewhere in comprising lava flows and domes, synvolcanic intrusions, and diverse volcamiclastic facies. The Mount Windsor Formation is 
composed of quartz-porphyritic rhyolitic lavas and intrusions, together with mimor felsic volcaniclastic facies. The Trooper Creek Formation is more varied in the volcanic facies types (lavas, sills, and cryptodomes and a wide variety of volcaniclastic facies) and in the compositions (basalt through to rhyolite). The presence of turbidite, suspension-settled mudstone and graptolite, and pelagic trilobite fossils (Henderson 1986) implies that most of the succession was deposited in a below-wave base, probably moderately deep marine environment. However, shallow-water facies have recently been identified (Doyle 1997), indicating that water depths varied spatially and temporally.

Studies of the volcanic facies in the Mount Windsor subprovince are limited to detailed research at the Thalanga and Highway-Reward massive sulfide orebodies. These two examples extend the spectrum of volcanic environments in which massive sulfides form and show interesting and important differences from Rosebery-Hercules and Hellyer in the Mount Read Volcanics. Both deposits occur at felsic volcanic centers, on one hand dominated by lavas and domes (Thalanga) and on the other by synvolcanic intrusions (HighwayReward). However, the two deposits contrast markedly in geometry in relationship to the host succession and in the pattern of hydrothermal alteration. Thalanga formed at or very close to the sea floor from exhaling hydrothermal fluids (Hill, 1996), whereas Highway-Reward formed by subsea-floor replacement, hydrothermal fluids being focused along the steep margins of shallow intrusions (Doyle and Huston, 1999).

\section{Setting of Thalanga}

The Thalanga massive sulfide lenses occur more or less conformably within a felsic lava- and dome-dominated succession close to the contact between the Mount Windsor Formation and the Trooper Creek Formation. The footwall succession is dominated by strongly quartz- and feldsparporphyritic rhyolitic lavas, including both coherent and autoclastic facies (hyaloclastite, resedimented hyaloclastite, autobreccia) on the order of $1,000 \mathrm{~m}$ thick. Despite strong alteration, diverse original textures (including perlite, spherulites, $\mathrm{mi}$ cropoikilitic texture, flow banding) and separate units have been identified (Paulick and McPhie 1999). The massive sulfide lenses occur in a complex succession of quartz- and feldspar-bearing, crystal-rich sandstone and breccia, quartzand feldspar-porphyritic rhyolitic lavas and synvolcanic sills, and peperite. The hanging-wall volcanic succession is about $200 \mathrm{~m}$ thick and dominated by feldspar-porphyritic dacitic lavas with that include significant volumes of autoclastic facies (hyaloclastite, resedimented hyaloclastite), polymictic felsic volcanic breccia, feldspar crystal-rich sandstone, feldspar- and pyroxene-porphyritic andesitic sills, and nonvolcanic mudstone and sandstone. Importantly, quartz-rich sandstone and rhyolite with quartz phenocryts previously thought to be restricted to the ore horizon are now known to occur in the hanging-wall succession as well (Paulick and McPhie 1999).

The Thalanga massive sulfide deposits formed at a submarine volcanic center dommated by the products of effusive rhyolitic eruptions, comprising lavas and domes, together with lava- or dome-derived, mass-flow-emplaced clastic units and synvolcanic intrusions (Fig. 5). The crest of this volcanic center could have been up to $500 \mathrm{~m}$ above the surrounding area, probably reflecting the constructional relief of the highaspect ratio lavas and domes. This setting resembles that of the PACMANUS hydrothermal field in the eastern Manus
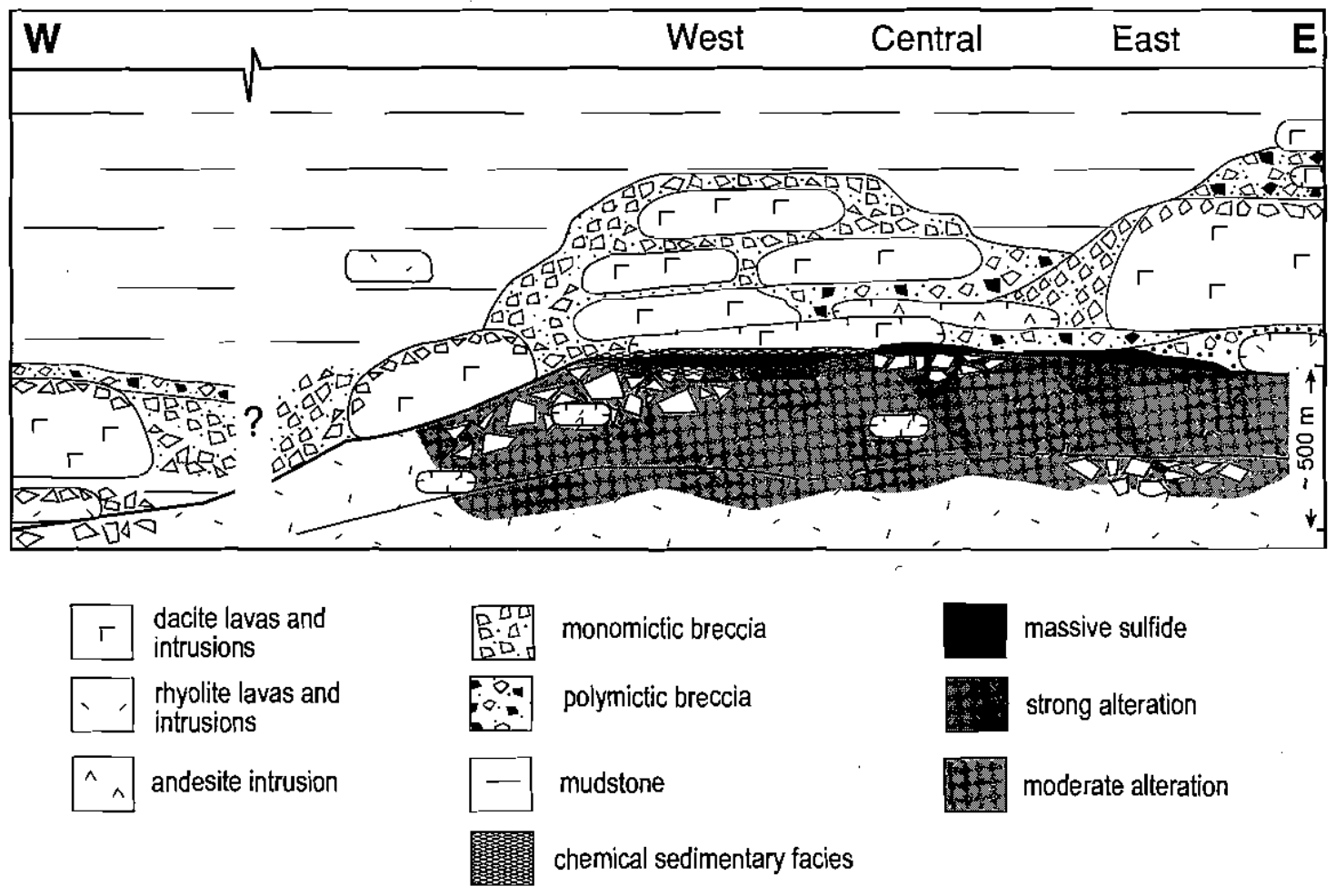

monomictic breccia

polymictic breccia

mudstone

chemical sedimentary facies

FIG. 5. Volcanic facies recoustruction of the enviroment of the Thalanga massive silfide deposit, Mount Windsor snbprovince, Qneensland (after Paulick and McPhie, 1999). 
basin (Papua New Guinea), which occnrs aț $\sim 1,600 \mathrm{~m}$ below sea level on the top of a 400 - to 600 -m-high ridge composed predominantly of dacitic lava (Binns and Scott, 1993). After ore formation, the Thalanga mine area remained a center of effusive volcamism and topographically high, although compositions of lava flows and domes shifted to dacite. The massive sulfides at Thalanga were buried by dacite lavas, synvolcanic intrusions, and thick, mass-flow-emplaced volcanic breccias composed of locally derived clasts. Hemipelagic mudstone and tnrbidite sand, partly derived from an nnknown possibly distal source, accumulated in surrounding lower lying areas.

Mapping of alteration in the footwall at Thalanga (Paulick 1999) has shown that the zones of intense alteration do not coincide either with particular facies boundaries or facies types and, instead, clearly crosscnt the facies arrangement (Fig. 5). Thalanga is important in this regard, illustrating a case where the facies architecture apparently had minimal in fluence on the ore-forming hydrothermal system.

\section{Setting of Highway-Reward}

The Highway-Reward massive sulfide pipes occur in a shallow intrusion-dominated felsic volcunic center (Doyle and McPhie, 2000; Fig. 6). The intrusions are interleaved with pumice breccia, crystal-rich sandstone, turbidites, and snspension-settled mndstone. Contact relationships and phenocryst populations (mineralogy, size, and percentages) indicate the presence of at least 13 distmct porphyritic units in a volume of $1 \times 1 \times 0.5 \mathrm{~km}^{3}$. More than 75 percent of the units have peperitic upper margins that demonstrate their emplacement into wet unconsolidated sediment as shallow sills and cryptodomes. A single partly extrusive cryptodome emerged at the sca floor, but the presence of additional lavas or partly extrusive cryptodomes is indicated by resedimented autoclastic breccia units.

Paleosea-floor positions at Highway-Reward are difficult to assign and in any case, they do not appear to have been favored locations for massive sulfide formation. Instead, hydrothermal fluids were constrained by the steep contacts of intrusions and focused within the porous and permeable, glassy, brecciated margins, promoting the formation of subsea-floor massive sulfide pipes (Doyle and Huston, 1999). This distinctive style of massive sulfide is also reflected in the distribution of alteration, zones of strong hydrothermal alteration, and pyrite-quartz-sericite stringer veins extending 150 $\mathrm{m}$ into the footwall and at least $60 \mathrm{~m}$ above the snlfide pipes.

\section{Volcanic influences on VHMS style}

Patterns shown by the deposits described above allow speculation that volcanic setting may be a significant influence on the style and metal content of VHMS deposits. In simple terms the more copper rich deposits appear to be associated with felsic volcanic centers dominated by subvolcanic intrusions (e.g., Highway-Reward), whereas the more zinc rich deposits are associated with both felsic (e.g., Rosebery, Thalanga) and mafic-intermediate (e.g., Hellyer; Que River) volcanic centers dominated by lavas and/or volcaniclastic facies. Studies by Amold and Sillitoe (1989) and Messenger et
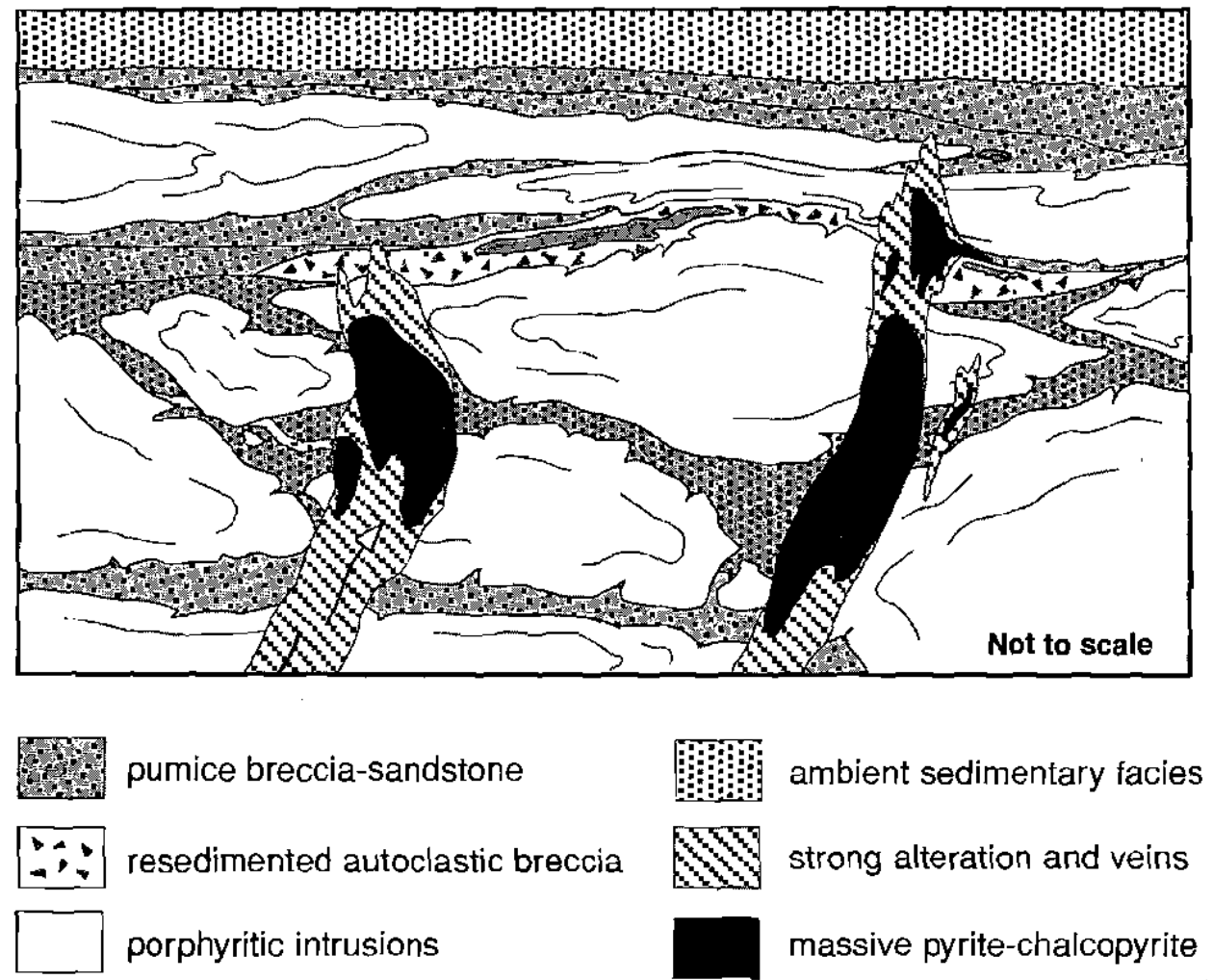

FIG. 6. Volcanic facies reconstruction of the enviroment of the Highway-Reward massive silfide deposit, Mount Windsar subprovince, Qucensland (after Doyle and McPbie, 2000). 
al. (1997) at Mount Morgan support this proposed relationship between $\mathrm{Cu}-\mathrm{Au}$ pyritic pipe ores and intrusion-related volcanic centers; however, the volcanic environment of Mount Lyell is too poorly understood to confirm the pattem.

Previous workers (e.g., Poulson and Hannington, 1995; Halley and Roberts, 1997) have demonstrated that the water depth can be an important control on gold/base nietal ratio; gold-rich, base metal-poor deposits such as Henty typically form in shallow-water volcanic settings, wliereas the base metal-rich deposits (e.g., Hellyer, Rosebery, Thalanga) are confined to deeper water volcanic settings (Fig. 3). The primary shape of the deposit may also be influenced by volcanic setting. Elongate mound-shaped deposits (e.g., Hellyer) form above major synvolcanic structures, in low-permeability volcanic facies that have focused hydrothermal fluid flow to the sea floor (Large, 1992). Multiple stratiform sheetlike lenses (e.g., Rosebery) are more likely to develop within permeable volcaniclastic facies, in which hydrothermal fluids are less focused and spread out laterally either below or onto the sea floor, forming thinner sheethike lenses at various stratigraphic levels.

The relationship between ore metal ratios and nature of the volcanic center probably relates to the temperature of the associated hydrothermal system. Thermodynamic modeling studies (e.g., Sato, 1973; Large, 1977, 1992; Ohmoto et al., 1983) and measurements of temperature of black smoker vents on the sea floor (e.g., Goldfarb et al., 1983; Scott, 1992) have shown that copper mineralizing vents are typically associated with higher temperature fluids $\left(>300^{\circ} \mathrm{C}\right)$ than the zinc mineralizing vents. Hydrothermal systems developed above or closer to synvolcanic intrusions are more likely to be hotter, and thus generate Cu-Au-rich ores, compared to the hydrothermal systems associated with lavas and volcaniclastic facies or located on the cooler flanks of volcanic edifices and distal from synvolcanic intrusions.

Spectrum of Deposits in the Mount Read Volcanics and the Mount Windsor Subprovince

The deposit descriptions and genetic interpretations presented above suggest that the ores of the Mount Read Volcanics and the Mount Windsor subprovince do not all belong to the same VHMS class. Rather, there is a continuum or spectrum from classical VHMS deposits (e.g., Hellyer, Thalanga), which formed on the sea floor in a moderate- to deepwater environment, to replacement, intrusion-related, copper-gold deposits, which appear to be transitional between VHMS and high-sulfidation epithermal (e.g., Mount Lyell and Highway-Reward), to shallow-water gold-rich stratabound replacement deposits that have some features akin to low-sulfidation epithermal ores. This spectrum is shown in a triangular diagram (Fig. 7) where the deposits have been plotted in terms of their attributes relative to end-member VHMS, porphyry $\mathrm{Cu}-\mathrm{Au}-\mathrm{Mo}$, and epithermal Au-Ag ores. The spectrum encompasses deposit styles that we might expect in a submarine volcanic setting, from shallow-water (epithermal) to moderate- to deep-water (VHMS), and from subvolcanic intrusion-related replacement (porphyry) to snbsea-floor replacement and sea-floor exhalative systenıs. Although we do not favor use of the term "high-sulfidation" VHMS for these hybrid-style massive sulfide and disseminated deposits, as proposed by Sillitoe et al. (1996), we do agree that their formation probably involved subsea-floor replacement, in relatively shallow water, with involvement of a magmatic fluid component.

This spectrum of submarine volcanic-hosted deposits is not considered to be unique to the Mount Read Volcanics and the

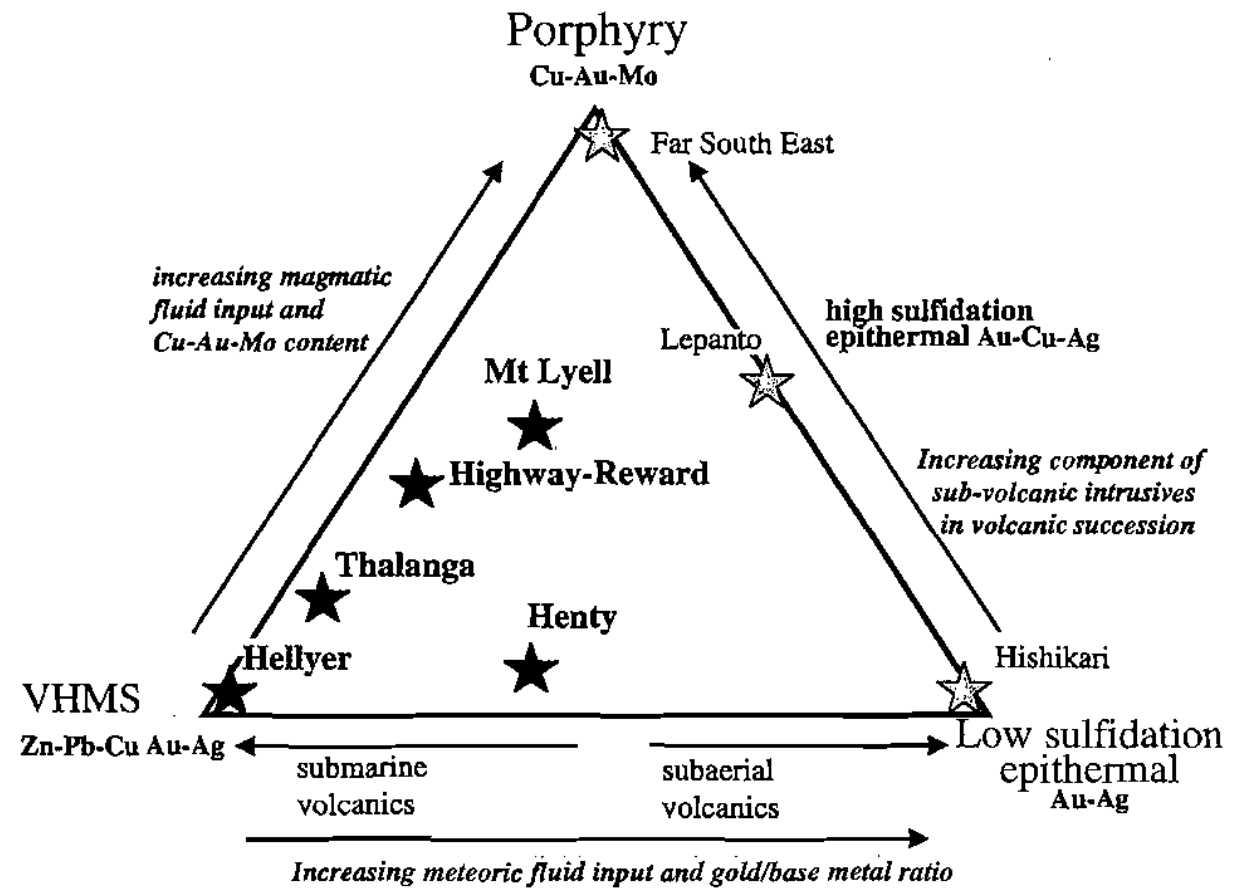

FlG. 7. Triangular representation showing the spectrum of ore deposits in volcanic successions, using selected deposits from the Mouut Read Volcanics and Mount Windsor subprovince as examples. 
Mount Windsor subprovince, but other cases probably occur in the major VHMS districts worldwide. Based on metal ratios, alteration assemblages, morphology, and volcanic environment, additioual examples of hybrid $\mathrm{Cu}$-Au-bearing massive sulfides that would plot within the triangle in Figure 7 are possibly the Horne and Bousquet deposits in the Abitibi district, Canada, the Gai and Kul-Yurt-Tau deposits in the Soulhern Urals, Russia, the Mount Morgan deposit in Eastern Australia, and the Bohden deposit in the Skellefte district, Sweden.

\section{Spectrum of Ore Deposit Alteration Halos}

The studies in this special issue on the character, extent, and composition of hydrothermal alteration and volcanic facies related to the Australian VHMS deposits discussed above enables a comparison of hydrothermal alteration across the spectrum of deposits.

\section{Morphology, zonation, and extent of halos}

The morphology and zonation of the hydrothermal alteration halos associated with the polymetallic ziuc-rich deposits (Rosebery, Hellyer, and Thalanga) and the pyritic $\mathrm{Cu}$-Au deposits
(Western Tharsis-Mt. Lyell and Highway-Reward) are shown in Figure 8, based on data from Doyle (2001), Cemmell and Fulton (2001), Herrmann and Hill (2001), Huston and Kamprad (2001), Large et al. (2001), and Pauhck et al. (2001). The polymetallic zinc-rich deposits each have an alteration envelope; which is typically elongate parallel to volcanic stratigraphy, with the footwall alteration more intense and more extensive than the hanging-wall alteration (Fig. 8a, b, c). In the copper-gold-bearing deposits, the alteration halo extends a greater distance into the hanging wall and appears to cut across volcanic facies boundaries (Fig. 8d, e). In all cases, there is a simple zonation from chlorite \pm quartz-rich alteration close to the ore lenses, to sericite-rich alteration farther away. In the polymetallic zinc-rich ores, the chlorite \pm quartzrich zone is commonly present immediately below the ore lenses (Fig. 8a, b, c) and is thickest and most intense below copper-rich parts of the orebody. At Hellyer (Fig. 8b), the chlorite and sericite alteration forms a zoned pipe, similar to those described for many Archean deposits in Canada (e.g., Sangster, 1972; Franklin et al., 1981); however, at Rusebery (Fig. 8a) the alteration zones are strata bound, and at Thalanga (Fig. 8c) there is evidence for a combination of pipes a ROSEBERY $\mathrm{Zn}-\mathrm{Pb} \pm \mathrm{Cu}$

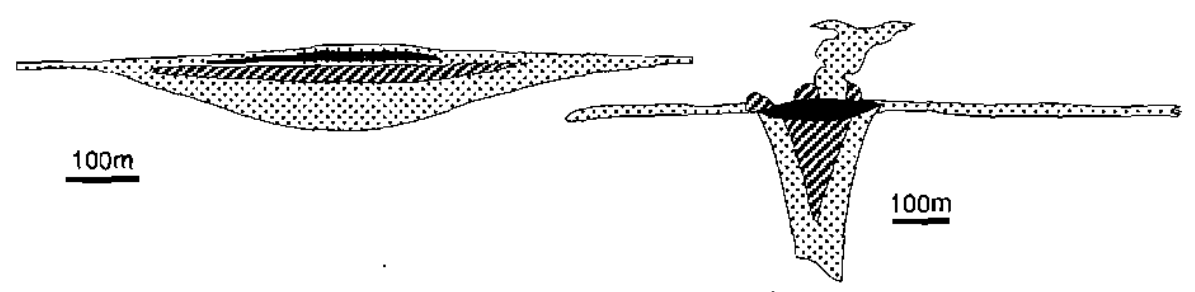

c THALANGA Cu-Zn-Pb

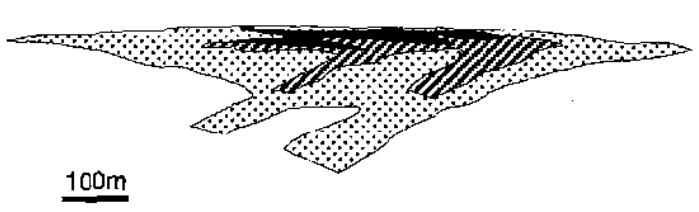

d WESTERN THARSIS CU-AU

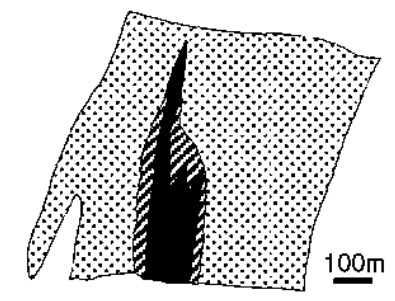

e HIGHWAY-REWARD CU-Au

f GOSSAN HILL Cu and $\mathrm{Cu}-\mathrm{Zn}$

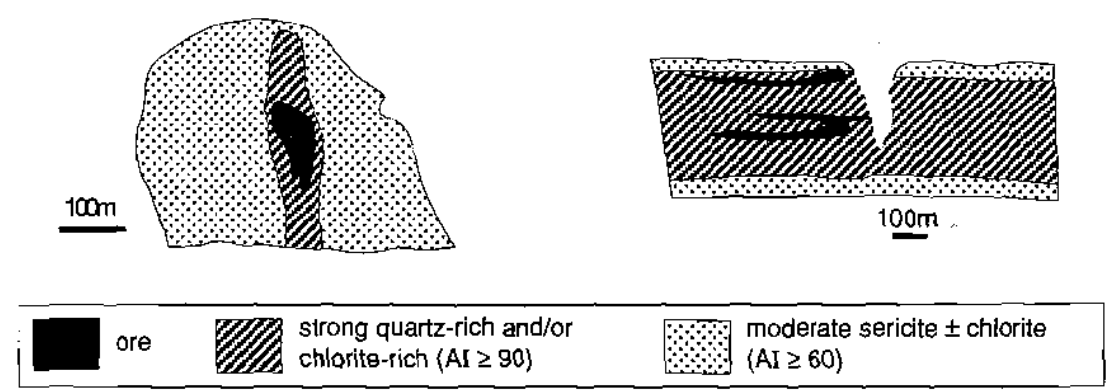

FiG. 8. Comparative sketches of alteration halos surrounding some $\mathrm{Zn}$-rich (a), (b), (c) and Cu-rich (d), (e), (f) orebodies in the Mount Read Volcanics, Mount Windsor subprovince, and Murchison province (WA). Abbreviation AI = Alteration Index. . 
and strata-bound zones. Previous workers (e.g., Morton and Franklin, 1987; Large, 1992) have discussed the importance of permeability and faults in the footwall as controls on ore fluid discharge and the formation of alteration pipes or stratabound zones.

The copper-gold pyritic ores commonly show intense chlorite \pm quartz alteration within and immediately surrounding the ore, both on the hanging-wall and footwall sides. The sericite \pm chlorite halo can be very extensive and commonly shows a symmetric pattern surrounding the chlorite \pm quartzrich zone (Fig. 8d, e). At Western Tharsis in the Mount Lyell field, Huston and Kamprad (2001, fig. 3) have recognized a pyrophyllite-rich alteration zone, which forms an overprinting zone surrounding the Cu-bearing chlorite \pm quartz-rich core. The zone contains other minerals (topaz, fluorite, zunyite, and alunite types), which together with pyrophyllite indicate advanced argillic alteration, similar to that found in high-sulfidation epithermal systems (White and Hedenquist, 1995). Although Highway-Reward is a similar Cu-Au-bearing system to Mount Lyell, no advanced argillic assemblages have been reported.

Alteration zonation related to the Henty strata-bound disseminated gold deposit is very different from that in the zincand copper-rich VHMS deposit discussed above. In the gold orebodies the alteration is concentrically zoned, with a core of massive microcrystalline silica showing marked aluminum depletion, surrounded by an intermediate silica-sericite zone, followed by an outer zone of silica-sericite-pyrite-chlorite (Callaghan, 2001). Footwall alteration consists of intense sericite \pm pyrite \pm carbonate, whereas hanging-wall alteration consists of albite-silica \pm chlorite in strata-bound zones intercalated with carbonate-altered volcaniclastics and bedded carbonate (Halley and Roberts, 1997; Callaghan, 2001). Thus, compared to the zinc- and copper-bearing VHMS systems, the Henty gold system shows more intense silica rich and aluminum depleted alteration close to ore and extensive albite alteration within the hanging wall, consistent with a subseafloor replacement origin. Callaghan (2001) interprets the intense silica enriched, aluminum depleted, alteration core to form from a highly acidic, possibly magmatic, flnid.

\section{Hanging-wall alteration}

As described above, the pyritic Cu-An deposits (Fig. 8d, e) are associated with extensive hanging-wall alteration (up to $200 \mathrm{~m}$ thick) of similar mineralogy but generally less intensity than the footwall alteration. This distribution reflects formation by subsea-floor replacement rather than exhalation (Large, 1992). The stratiform sheetlike zinc-rich deposits at Rosebery and Thalanga (Fig. 8a, c) show little obvious visual hanging-wall alteration in drill core; however, hthogeochemical studies at Rosebery (Large et al., 2001) have revealed a weak chemical halo, indicated by the whole-rock $\mathrm{Ba} / \mathrm{Sr}$ ratio and $\mathrm{Mn}$ content of carbonate, extending up to $100 \mathrm{~m}$ into the hanging-wall volcaniclastics. No similar hanging-wall halo has been defined at the Thalanga deposit (Paulick et al., 2001).

Hellyer is unusual as it is the only Paleozoic polymetallic VHMS deposit to exhibit a well-developed hanging-wall alteration zone. Studies by Gemmell and Fulton (2001) have defined a distinctive and zoned alteration plume overlying the central part of the deposit within the hanging-wall basalts.
Five alteration zones have been identified: fuchsite, chlorite, carbonate (calcite), quartz-albite, and sericite. Fuchsite-dominated alteration occupies the central portiou of the hangingwall alteration plume. Chlorite and carbonate alteration surrounds the fuchsite zone with carbouate zones forming near to the ore deposit, and chlorite zones extending above and lateral to the carbonate. Outward is quartz-albite alteratiou, which extends laterally into distal sericite alteration. After rapid burial of the deposit by basalt, continuation of upward hydrothermal flrid flow created the zoned hanging-wall alteration. Distributiou of hanging-wall alteratiou assemblages suggests a temperature gradient from a higher temperature core (fuchsite) to a lower temperature rim (quartz-albite and sericite; Gemmell and Fulton, 2001).

In contrast to the crosscutting carbonate-bearing and quartz-albite zones at Hellyer, similar, but strata-bound, carbonate and quartz-albite \pm chlorite alteration lenses are present in the hanging wall of the Henty gold-rich volcanogenic ores (Large, C.P., 1995; Callaghan, 2001). It is significant from an exploration perspective, that whereas albite destruction is a ubiquitous feature of footwall alteration in the VHMS system, albite addition may be present in the hanging wall of some $\mathrm{Zn}$ - and Au-rich VHMS deposits.

\section{Carbonate alteration}

The distribution of carbonate alteration in the five deposits studied is shown in Figure 9. Iu the stratiform zinc-rich deposits, carbonate is commonly developed in either the chlorite- or sericite-beariug zones close to ore (Fig. 9a, b, c). In coutrast the copper-gold ores show less or no significant carbonate alteration, and if presentit is developed within an outer propylitic-type alteration halo surrounding the sericite zone (Fig. 9d). Hydrothermal carbonate is generally present as clisseminated spots comprising 2 to 20 wt percent of the altered rock, although massive carbonate zones occur above, below, or lateral to zinc-lead ore at Rosebery and Thalanga. Textural evidence (e.g., Khin Zaw and Large, 1992; Sharp and Gemmell, 2001) and chemical evidence (e.g., Herrmann and Hill, 2001; Large et al., 2001) indicate that the carbonate zones form by infill of porosity and selective replacement of various components of the volcanic rocks, rather than by direct precipitation on the sea floor. Studies by Allen et al. (1998) of carbonate alteration in the Rosebery-Hercules area of the Mount Read Volcanics indicate that carbonate alteration distal to ore is generally low intensity and not texturally destructive, ocurring as disseminatious, filling primary porosity such as vesicles and replacing or rimming glass shards and feldspar phenocrysts, in advanced stages. However, close to ore, more intense carbonate alteration masks primary volcanic textures, resulting in fine-grained massive homogeneous pale-colored rock. The alteratiou carbonate minerals are commonly complex mixtures of Fe-Mn-Mg-Ca carbonates, as summarized in Figure 9. At Rosebery the carbonates are commonly $\mathrm{Mn}$ rich (Large et al., 200L), whereas at Hellyer, Western Tharsis, and Gossan Hill ferroan dolomite, ankerite, and siderite are the common species.

Chlorite-tremolite-dolomite-calcite assemblages are prominent in thin strata-bound zones in, and laterally adjacent to, the western ore leuses at Thalanga. Their major elemeut, immobile trace element, and isotopic compositions indicate they 
a ROSEBERY

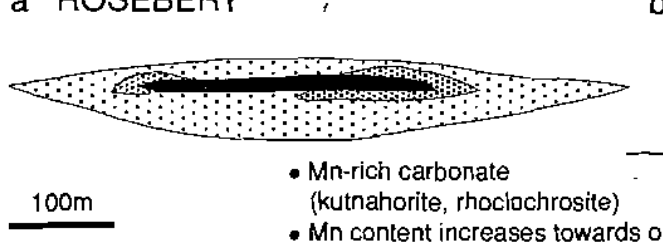

c THALANGA
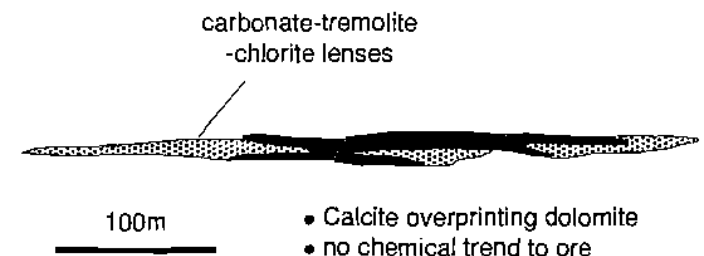

e GOSSAN HILL

- Ankerite \& siderite - no trends to ore

- most Mn-rich carbonate in zinc ore \& veins

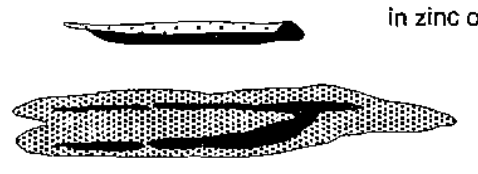

b HELLYER

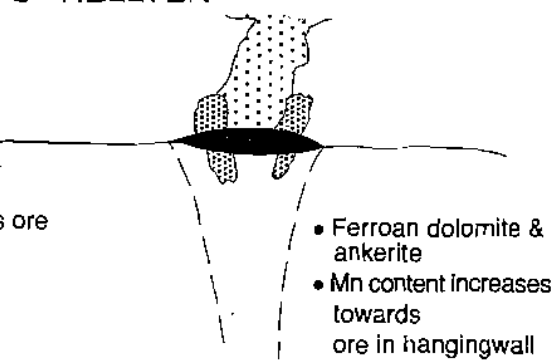

d WESTERN THARSIS
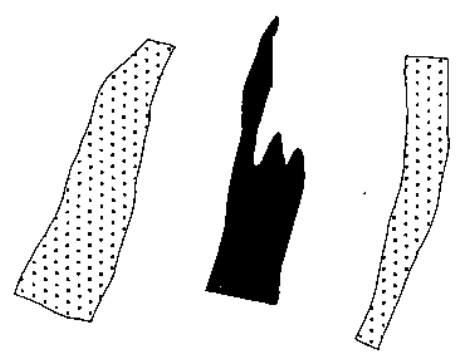

- Ankerite \& siderite

- Fe content of

carbonate increases

to ore

FIc. 9. Comparative sketches showing extent of carbonate alteration at Rosebery, Hellyer, Thalanga, Western Tharsis, and Gossan Hill.

are the metamorphic products of chlorite-dolomite assemblages that originated by hydrothermal alteration of rhyolitic volcanics, close to the paleosea floor (Herrmann and Hill, 2001). The chlorite and tremolite have magnesian compositions that do not show systematic lateral variations in relationship to ore. Dolomite and calcite have nearly ideal compositions. Dolomite contains up to 0.02 and 0.06 cations per formula unit of iron and nuanganese. Tron content of dolomite increases slightly toward the central ore lens $(<0.005-0.02$ cations $)$ but there is no systematic spatial variation in manganese.

Bedded carbonates and carbonate-altered volcaniclastic facies are features of the Henty deposit (Halley and Roberts, 1997; Callaghan, 2001). The carbonate minerals (dominantly calcite) occur both in the footwall alteration zone (sericitepyrite-carbonate) and as massive lenses in both the footwall and hanging wall.

Early studies of the carbonate lenses at Rosebery, Thalanga, and Henty (Braithwaite, 1974; Gregory et al., 1990; Halley and Roberts, 1997) concluded that they were of exhalative origin forming distal to the sea-floor sulfide lenses. However, in each case, more recent work has demonstrated their infill and replacement origin, involving mixing of hydrothermal fluid and seawater below the paleosea floor, in permeable volcanic units (e.g., Herrmann and Hill, 2001). Khin Zaw and Large (1992) used the isotopic composition of the ore-related carbonate minerals to interpret a seawater source for both carbon and oxygen. Callaghan (2001) used isotopic data on the carbonates at Henty to suggest that they resulted from a district-wide magmatic $\mathrm{CO}_{2}$ devolatilization event, which commenced during early hydrothermal activity and continued for a period beyond ore formation. Carbonate deposition resulted from mixing of small amounts of a magmatic $\mathrm{CO}_{2}$-rich fluid with seawater at, or below, the paleosea floor (Callaghan, 2001).

\section{Volcanic influences on alteration styles in VHMS successions}

The facies architecture of submarine volcanic successions that host VHMS deposits is inherently complicated, and additional stratigraphic and structural complexities may be introduced by the synvolcanic intrusions and synvolcanic faults. Sites of ore deposition are highly variable and may comprise thick lava and breccia successions (e.g., Hellyer, Thalanga), synvolcanic intrusions (e.g., Highway-Reward), and volcaniclastic mass-flow units (e.g., Rosebery and Hercules). Orebodies may have formed in shallow subsea-floor settings as replacements of volcaniclastic (e.g., Rosebery and Hercules) or synvolcanic intrusions (e.g., Highway-Reward), or else at the sea floor (e.g., Hellyer).

Even though submarine volcanic successions are potentially immensely complex, their initial response to alteration is at least in part predictable. Factors that appear to influence responses to alteration include the presence of volcanic glass, the porosity and permeability (including fracture density and faulting), the rock composition, and external conditions such 
as pressure, temperature, fluid composition, and fluid/rock ratio. Of particular importance is the presence of volcamic glass and the porosity and permeability characteristics.

Proportion and distribution of glassy versus crystalline domains: Submarine lavas, high-level intrusions, and some volcaniclastic facies are commonly initially glassy or at least partly glassy (Fig. 10). Once formed, both the texture and composition of volcarric glass may be partially or completely modified by a variety of processes, such as hydration, devitrification (crystallization below the glass transition temperature), diagenetic alteration, and compaction. The rate at which these modifications proceed is in general accelerated by the presence of water and by elevated temperature. In contrast, crystalline components of volcanic facies are generally unaffected by hydration and compaction and may remain largely stable during diagenetic alteration. Thus, glassy domains will undergo longer and more complex textural evolution and exlibit greater compositional changes than crystalline
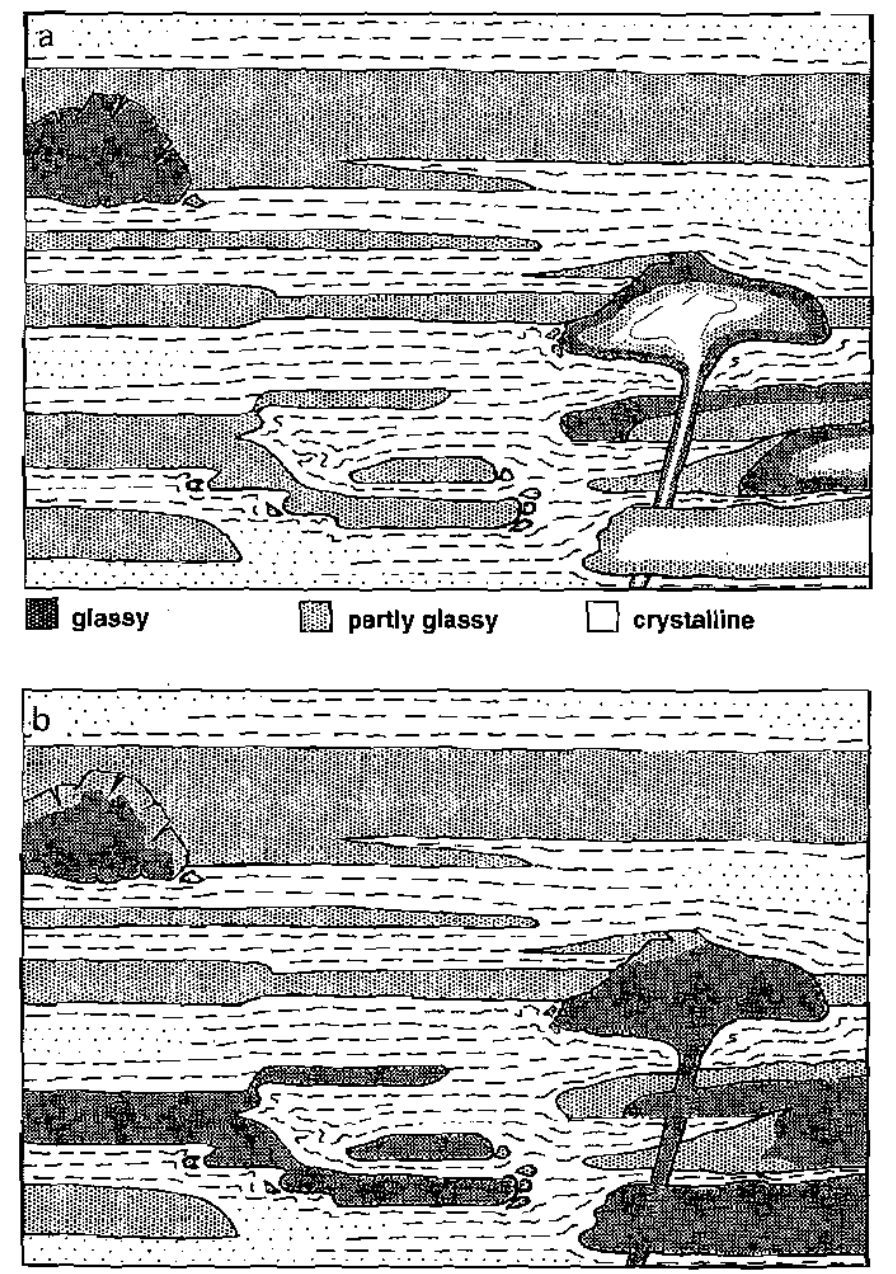

matrix-controlled porosity

FIG. I0. a. Abundance and distribution of glassy, partly glassy, and crystalline domains within the principal volcanic facies types found im submarine volcanic successions. b. Distribution of fracture- vs. Inatrix-controlled porosity in the principal volcanic facies types found in submarine volcanic successions. The coherent parts of lavas and intrusions have fracture-controlled porosity, whcreas the porusity of volcanielastic facies is matuix controlled (after Mc Phie et al., 1993). domains in the same facies. This generalization ho scales ranging from millimeters, such as in the case of versus crystalline flow laminae in lavas, to meters, sucl the case of glassy margins versus the crystalline inter. lavas and synvolcanic intrusions.

Porosity and permeability characteristics: The ext physical and chemical interaction of various volcanic with seawater, diagenetic fluids, and/or hydrothernal depends on the porosity and permeability. These prof vary enormously among different volcanic facies types tially within some volcanic facies, and also temporally, the time of emplacement through compaction and diag alteration. However, in simplest terms, coherent and volcanic facies show fundamentally different styles of $\mathrm{pc}$ and permeability (Fig. 10)

Coherent domains of lavas and intrusions are dominat fracture-controlled porosity and permeability. This style in scale from very large (melers) quench fractures or $\mathrm{c}$ joints to very small (millimeters) perlitic fractures. The f generally prevail in the interior of lavas and synvolcan trusions, whereas the latter may occur in any glassy domair in glassy clasts. In volcaniclastic facies, the interparticl intraparticle pores control porosity and permeabilty, so type (pumice or scoria versus nonvesicular clasts), grain and sorting are all important. Well-sorted pumice br such as that forming the footwall to the Rosebery and cules inassive sulfide deposits, at least initially has unif high porosity and permeability. Poorly sarted mixtures of $s$. crystals, and dense volcanic clasts (for example, resedim autoclastic facies) have lower and more heterogeneous $\mathrm{F}$ ity and permeability. The matrix character and abundanc particularly important in poorly sorted aggregates.

Thus, there is a wide spectrum in the textural and co sitional responses of different volcanic facies to diagene other alteration even within one succession. Glass-ricl more porous and permeable facies in submarine volcani cessions are the most easily affccted. The textural and positional contrasts that initially exist between glassy and talline domains will persist during, and influence, any alteration, including alteration related to VHMS ore-for hydrothermal activity.

\section{Chemical mass changes}

The intense hydrothermal alteration of the footwall of VHMS deposits may be associated with significant chan: the mass of mobile chemical components (e.g., Barret MacLean, 1991, 1994; Barrett et al., 1993). Estimates mass changes in variably altered and spatially related samples have been used in lithogeochemical explos (MacLean and Barrett, 1993; Galley, 1995). This tech has not been widely applied in Australian VHMS dis However, the available data for Australian deposits in that large net mass gains associated with silicification footwall zones are typical. This pattern contrasts with net losses im the chloritic zones that exist beneath some Car VHMS deposits (e.g., Noranda; Barrett and MacLoan, 199

Gemmell and Large (1992) applied a modified i. method to estimate mass changes in the zoned alteration beneath the Hellyer deposit. They found that alteration stringer envelope, sericitic, chloritic, and siliceous core 
involved net mass gains of $4 / 100 \mathrm{~g}, 2 / 100 \mathrm{~g}, 18 / 100 \mathrm{~g}$, and $108 / 100 \mathrm{~g}$, respectively. These zones reflect increasing alteration intensity from the onter shell to the inner core of the snbvertical feeder system. All the zones lost substantial $\mathrm{Na}_{2} \mathrm{O}$ and minor $\mathrm{CaO}$. The major gains were in $\mathrm{Fe}_{2} \mathrm{O}_{3}, \mathrm{~S}$, and $\mathrm{SiO}_{2}$, with additional shight gains in $\mathrm{K}_{2} \mathrm{O}$ in most zones, and $\mathrm{MgO}$ in the sericitic and chloritic zones (Table 2). Paradoxically, the chlorite zone appears to have lost $\mathrm{SiO}_{2}(-13 / 100 \mathrm{~g})$. That contrasts with the $\mathrm{SiO}_{2}$ gains in the adjacent sericitic and siliceous core zones (13 and 95/100 g, respectively).

At Thalanga, most footwall alteration zones were associated with net mass gains up to about $50 / 100 \mathrm{~g}$; mainly attributable to large gains in $\mathrm{SiO}_{2}$ (Herrmann and Hill, 2001). The pyritic stringer zones also gained substantial $\mathrm{Fe}_{2} \mathrm{O}_{3}$ and $\mathrm{S}$, and the peripheral siliceous white rhyolite zones gained minor $\mathrm{K}_{2} \mathrm{O}$. In contrast, some volumetrically small footwall sericite-chlorite and chlorite-tremolite zones are characterized by net mass losses due to significant losses of $\mathrm{SiO}_{2}$. All Thalanga footwall alteration zones exhibit major or total loss of $\mathrm{Na}_{2} \mathrm{O}$.

Consideration of limited geochemical data from Rosebery (Large et al., 2001) suggests that the footwall alteration was also mainly associated with net mass gains, dominated by significant gains in $\mathrm{SiO}_{2}$. Estimates of absolute mass changes for variably altered samples from beneath the $\mathrm{K}$ lens reveal losses of $\mathrm{Na}_{2} \mathrm{O}$ in all the footwall hydrothermal alteration assemblages (Table 2). With the exception of a shight loss of $\mathrm{SiO}_{2} \mathrm{~m}$ the chloritic zone inmediately below the ore, all other footwall-altered samples exhibit minor to large gains of $\mathrm{SiO}_{2}$ (Table 2).

\section{Conditions of formation of hydrothermal alteration in VHMS systems}

Previous workers (e.g., Large, 1977; Riverin and Hodgson, 1980; Lydon and Galley, 1986) have suggested that alteration zonation in the footwall of VHMS deposits probably reflects fluid/rock interaction controlled by decreasiug temperature with distance from the center of the hydrothermal upflow zones. However, the Mg-free nature of modern sea-floor hydrothermal fluids suggests that $\mathrm{Mg}$-bearing chlorite development in footwall alteration zones most likely relates to the entrainment of seawater into the hydrothermal system (Roberts and Reardon, 1978; Lydon, 1988).

The idea of alteration zonation due to a decreasing thermal and fluid/rock ratio has been tested and refined by Schardt et al. (2001) in a thermodynamic model designed to reproduce the zonation present in the footwall alteration pipe at Hellyer, passing from the silica-rich core, through a chlorite-rich shell, to the sericite-rich envelope. Schardt et al. (2001) have shown that alteration mineral zonation depends principally on variations in temperature, $\mathrm{pH}$, redox state, and reaction progress (or fluid/rock ratio), as hydrothermal fluids move outward. from the center to edges of the alteration system. The classic footwall zonation of quartz $\rightarrow$ chlorite $\rightarrow$ sericite at Hellyer was reproduced by reacting a fluid at $250^{\circ}$ to $350^{\circ} \mathrm{C}$ (starting temperatures) and $\mathrm{pH}$ of 4.5 to 5.0 with andesite over a decreasing flnid/rock ratio from 50,000 down to 20 . Reactions during cooling over the temperature range $350^{\circ}$ to $100^{\circ} \mathrm{C}$ reproduced the fnll range of footwall alteration assemblages. The $\mathrm{pH}$ of the reacting fluid showed hittle variation $(4.5-4.0)$ during reaction progress (Schardt et al., 2001). Mg-rich chlorite formed in the inner chlorite-rich zone and Fe-rich chlorite developed in the outermost part of the sericite zone, similar to the pattern observed in many massive snlfide deposits (Urabe et al., 1983). This modeling was carried out employing an Mg-bearing ore fluid, with the assumption that a component of seawater $\mathrm{Mg}$ was entrained into the ore fluid at depth. Further coupled flnid flow-fluid chemical modeling is planned to study footwall chlorite formation related to the interaction of an upwelling $\mathrm{Mg}$-free hydrothermal fluid with advected $\mathrm{Mg}$-bearing seawater, as proposed by several workers (e.g., Roberts and Reardon, 1978; Franklin et al., 1983).

The modeling by Schardt et al. (2001) demonstrated that, for the case of Mg-bearing hydrothernal fluids, extensive chlorite alteration zones are favored by higher temperatures $\left(>250^{\circ} \mathrm{C}\right)$ and less acidic $\mathrm{pH}(4.5-5.5)$ fluids. Sericite-dominated alteration, on the other hand, forms at lower temperatures $\left(<250^{\circ} \mathrm{C}\right)$ and more acidic conditions $(\mathrm{pH}=4.0-4.5)$. At lower $\mathrm{pH}$, kaohinite and pyrophyllite are stabihzed, and at higher $\mathrm{pH}$ and lower temperatures $\left(<200^{\circ} \mathrm{C}\right), \mathrm{K}$ feldspar becomes an important component of the outermost alteration

TABLE 2. Sumnary of Major (absolute) Mass Changes in Alteration Zones Associated with Hellyer, Rosebery, and 'Thalanga Massive Sulfide Deposits

\begin{tabular}{|c|c|c|c|c|}
\hline Deposit & Alteration zone & Net mass change ( $g / 100 g)$ & Major mass gains & Major mass losses \\
\hline \multirow{4}{*}{ Hellyer } & Siliceous core & 108 & $\mathrm{Si}, \mathrm{Fe}, \mathrm{S},(\mathrm{K})$ & $\mathrm{Na},(\mathrm{Ca})$ \\
\hline & Chlorite & 18 & $\mathrm{Fe}, \mathrm{Mg}, \mathrm{S}$ & $\mathrm{Si}, \mathrm{Na},(\mathrm{Ca})$ \\
\hline & Sericite & 2 & $\mathrm{Si}, \mathrm{Fe}, \mathrm{S},(\mathrm{K})$ & $\mathrm{Na},\langle\mathrm{Ca}\rangle$ \\
\hline & Stringer envelope & 4 & $\mathrm{Si}, \mathrm{S}, \mathrm{Fe},(\mathrm{K})$ & $\mathrm{Na},(\mathrm{Ca})$ \\
\hline \multirow[t]{3}{*}{ Rosebery } & Quartz-sericite & $\sim 10-60$ & $\mathrm{Si}, \mathrm{Fe}, \pm\left(\mathrm{S}, \mathrm{K}, \mathrm{CO}_{2}\right)$ & $\mathrm{Na}$ \\
\hline & Sericite & $\sim 10-30$ & $\mathrm{Si},\left(\mathrm{K}, \mathrm{CO}_{2}\right)$ & $\mathrm{Na}$ \\
\hline & Chlorite & $\sim 0$ & $\mathrm{Mg}$ & $\mathrm{Si}, \mathrm{Na}$ \\
\hline \multirow[t]{6}{*}{ Thalanga } & Chlorite-tremolite-carbonate (CTC 2 and 3) & 147 & $\mathrm{Ca}, \mathrm{Mg}, \mathrm{CO}_{2}(\mathrm{Fe}, \mathrm{S}, \mathrm{Zn})$ & $\mathrm{Na}, \mathrm{K}$ \\
\hline & Chlorite-tremolite (CTC 1) & -28 & $\mathrm{Mg},(\mathrm{Fe}, \mathrm{S})$ & $\mathrm{Si}, \mathrm{Na}$ \\
\hline & Qtz-Py stringer zones & 52 & $\mathrm{Si}, \mathrm{Fe}, \mathrm{S}$ & $\mathrm{Na}$ \\
\hline & Qtz-Ks white rhyolite & 47 & $\mathrm{Si}, \mathbf{K}$ & $\mathrm{Na}$ \\
\hline & Qtz-Ser-Chl moderately altered rhyolite & 19 & $\mathrm{Si},(\mathrm{Fe}, \mathrm{S})$ & $\mathrm{Na}$ \\
\hline & Ser-Chl foliated rbyobte & -27 & $(\mathrm{Mg})$ & $\mathrm{Si}, \mathrm{Na}$ \\
\hline
\end{tabular}

Abbreviations: $\operatorname{chl}=$ chlorite, $\mathrm{Ks}=\mathrm{K}$ feldspar, $\mathrm{Py}=$ pyrite, $\mathrm{qtz}=$ quartz 
zone (Schardt et al., 2001). The modeling supports previous interpretations (e.g., Walshe and Solomon, 1981) that intense chlorite and quartz rich alteration associated with coppergold VHMS deposits results from high-temperature hydrothermal systems $\left(>300^{\circ} \mathrm{C}\right)$, whereas sericite-dominated alteration associated with zinc-lead-silver ores results from lower temperature hydrothermal systems $\left(<200^{\circ} \mathrm{C}\right)$. At intermediate temperatures $\left(200^{\circ}-300^{\circ} \mathrm{C}\right)$, mixed chlorite-sericite assemblages are typically developed. Carbonate alteration was not considered by Schardt et al. (2001); however, it is likely that significant carbonate alteration, particularly chlorite-carbonate assemblages, mdicates more alkaline conditions that may develop where hot, near-neutral hydrothermal fluids have mixed with, and heated, entrained seawater, leading to saturation of carbonate at the periphery of the hydrothermal upflow zones.

\section{Alteration Vectors Useful for Exploration}

A summary of the alteration vectors discussed in the papers of this special issue is given below. The reader is also referred to an excellent review on this topic by Galley (1995), which is based principally on case studies of Canadian VHMS deposits.

\section{Mineral zonation vectors}

Zonation from sericite-rich alteration assemblages to more chlorite- or quartz-rich alteration has been recognized for some time as an empirical vector toward the center of hydrothermal systems associated with VHMS deposits (e.g., Sangster, 1972; Lydon, 1984). Chlorite-rich alteration is more common close to copper-rich ores, especially those containing magnetite or pyrrhotite, such as the Archean Noranda-type $\mathrm{Cu}-\mathrm{Zn}$ deposits (e.g., Franklin, 1995), and quartz-rich alteration may be present close to gold-rich ores (e.g., Henty). Carbonate alteration may occur in both the chlorite and sericite zones but is more commonly associated with the zinc(e.g., Rosebery, Thalanga) and gold-rich deposits (e.g., Henty) than the copper-rich deposits.

The most intense carbonate alteration is commonly laterally adjacent to inferred fluid upflow zones and probably developed in porous volcanic units where the hydrothermal fluids mixed with seawater (e.g., Thalanga; Herrmann and Hill, 2001).

\section{Major element lithogeochemical vectors}

All deposits studied in this investigation show zones of plagioclase destruction and sodium depletion in the footwall. Similar zones of sodium depletion have been known about, and applied in, mineral exploration for the Kuroko deposits of Japan and the Archean massive sulfide deposits of Canada for over 30 yr (Franklin et al., 1981). These zones are commonly associated with iron and magnesium enrichment, depending on the degree of pyrite and chlorite alteration, the $\mathrm{Fe} / \mathrm{Mg}$ ratio of the chlorite, and the original composition of the volcanic rock. Potassium may be enriched or depleted within the alteration zone, depending on the ratio of sericite to chlorite. The following three lithogeochemical approaches based on variations in whole-rock composition may serve to define vectors to ore: (1) ratios such as the Ishikawa alteration index (AI) and the chlorite-carbonate-pyrite index (CCPI), which track the chemical and mineralogical changes associated with hydrothermal alteration (Ishikawa et al., 1976; Large et al., 2001); (2) Pearce element ratios (Stanley and Madeisky, 1994), which involve mathematic treatment of the whole-rock data to distinguish igneous fractionation and volcanic component mixing trends from hydrothermal alteration associated with mineralization; and (3) determination of elemental mass changes associated with hydrothermal alteration, using the procedure of Gresens (1967), modified by Grant (1986), in conjunction with immobile element chemostratigraphy (Barrett and MacLean 1994; Barrett et al., 2001).

The first of these methods combines two alteration indices, $\mathrm{AI}$ and CCPI, to produce the alteration box plot and is simple and easily applied in the exploration context. It has the added advantage of relating chemical to mineralogical changes in a graphic method, highlighting any trends that may be spatially related to VHMS ores (Fig. 11; Large et al., 2001)

Figure 11 depicts the most common alteration trends generated by hydrothermal systems associated with VHMS deposits. Least altered volcanic samples plot within a central box with an $\mathrm{AI}=20$ to 65 and a CCPI $=15$ to 85 , depending on primary composition (Large et al,, 2001, fig. 7). Hydrothermally altered samples define a trend to the right, depending on the relative significance of sericite, chlorite, pyrite, $\mathrm{K}$ feldspar, and carbonate alteration. Diagenetic alteration, which imcludes albite, epidote, paragonite, and calcite, and some types of weak hanging-wall alteration, produces trends to the left on the box plot.

\section{Mineral composition vectors}

Previous studies have emphasized the composition of chlorite, in particular the variation in $\mathrm{Fe} / \mathrm{Mg}$ ratio, as a vector to mineralization (e.g., Urabe and Scott, 1983; McLeod and Stanton, 1984; Lydon, 1988). However, research in the Mount Windsor and Mount Read volcanic successions suggests that subtle changes in the composition of white mica may be just as useful (Herrmann et al., 2001; Huston and Kamprad, 2001; Large et al., 2001).

Herrmann et al. (2001) have shown that spectral analysis of rock samples by short wavelength infrared analysis (SWIR) using the PIMA can reveal changes in the $\mathrm{Fe}$ and $\mathrm{Mg}$ content ("phengicity"), Si/Al ratios, and the $\mathrm{Na} /(\mathrm{Na}+\mathrm{K})$ ratios of white mica. White mica in the symmetrical hydrothermal alteration zones surrounding the pyritic $\mathrm{Cu}-\mathrm{Au}$ deposits at Western Tharsis (Mt. Lyell, Tasmania) and Highway Reward (Mt. Windsor subprovince, Queensland) vary systematically in composition from phengite at the outer edge of the alteration to sodic muscovite close to ore. At Rosebery, a zone of phengitic white mica surrounds the ore zone, and a zone of sodic white mica occurs in a volcaniclastic unit above the highest grade ore. The most barium rich mica (between 5 and $10 \% \mathrm{Ba}$ ion substituting for $\mathrm{K}$ ) occurs close to ore in the immediate hanging-wall and footwall positions.

Although our research shows that there are significant variations in chlorite composition surrounding VHMS deposits, there is no common and systematic pattern related to the distance from the ore. This is at variance with studies elsewhere which have shown that the $\mathrm{Mg}$ content of $\mathrm{Fe}-\mathrm{Mg}$ chlorite commonly increases passing from the margin to the core of the footwall alteration system (e.g., Seneca, Southbay, and Corbet deposits; Urabe et al., 1983). In contrast, in the 


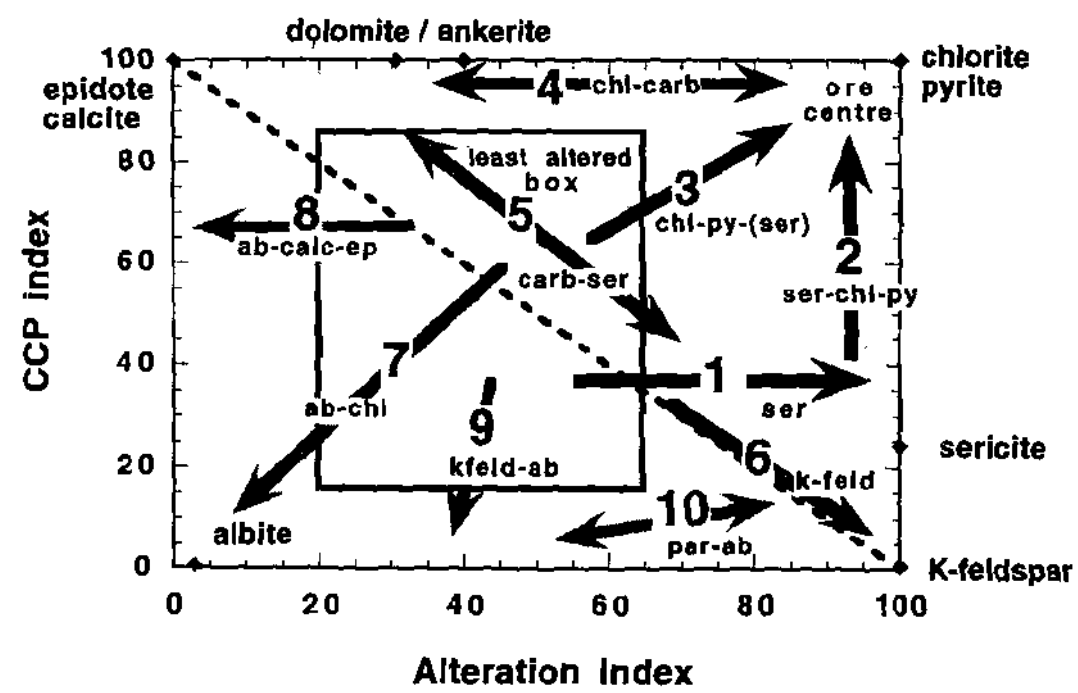

Fig. 11. Alteration index (Al)-chionite-carbonate-pyrite index (CCPI) box plot showing principal hydrothernal and diagenetic aiteration trends in suhmarine voleanics associated with VHMS deposits (from Large et al., 2001). AI = 100(MgO + $\left.\mathrm{K}_{2} \mathrm{O}\right) /\left(\mathrm{MgO}+\mathrm{K}_{2} \mathrm{O}+\mathrm{Na}_{2} \mathrm{O}+\mathrm{CaO}\right), \mathrm{CCPI}=100(\mathrm{FeO}+\mathrm{MgO}) /\left(\mathrm{FeO}+\mathrm{MgO}_{2}+\mathrm{Na}_{2} \mathrm{O}+\mathrm{K}_{2} \mathrm{O}\right)$.

Bathurst district also in Canada, the reverse pattern has been recordcd, with the $\mathrm{Fe}$ content of chlorite increasing toward the alteration core (e.g., Hcath Steele, Lentz et al., 1997; Brunswick 2, Luff et al., 1992). Thalanga is the only deposit in this program of study where a consistent trend of chlorite composition has been recorded. Paulick et al. (2001) have identified an increase in the $\mathrm{Mg} /(\mathrm{Mg}+\mathrm{Fe})$ ratio of hydrothermal chlorite toward the ore from values of 40 to $50 \mathrm{in}$ the least altered footwall rhyolites to 85 to 95 in the footwall rhyolites close to ore. Although no trends were defined at Rosebery and Hellyer, our research indicates that chlorite close to ore, or within the ore host stratigraphy, tends to be $\mathrm{Mg}$ rich, whereas chlorite outside the alteration zones tends to be Fe rich (Genmell and Fulton, 2001; Large et al., 2001). Studies in the Mount Read Volcauics (Herrmann et al., 2001) have shown that in most regional and weakly altered zones distal to massive sulfides where fluid/rock ratios are low, the chlorite composition is controlied by the bulk-rock composition, rather than a position relative to mineralization.

Of all minerals studied here, carbonates seem to have the most potential as vectors to ore, both in hanging-wall and footwall alteration. Distal carbonate, in small amounts (2-10 wt \%), within least aitered volcanic samples commonly has a relatively pure dolomite or calcite composition. Alteration dolomite commonly shows an increase in iron and/or manganlese content as it approaches the ore. For example, at Rosebery thc $\mathrm{MnCO}_{3}$ content of dolomite increases systematically from values of 1 to 10 molc percent in the outer alteration envelope to values of 50 to 95 mole percent close to the ore (Large et al., 2001). At Hellyer, the Mn content of dolomite and ankerile in the hanging wall increases toward the ore (Gemmell and Fulton, 2001), whereas at Western Tharsis, the Fe content of ankerite and siderite in the outer envelope of the alteration system increases toward the ore (Huston and Kamprad, 2001). Similar trends in carbonate composition (dolomite to Mn-bearing siderite) have been recorded in the footwall alteration zone of the Mattabi VHMS deposit, Canada (Franklin et al., 1975).

\section{Thallium and antimony halos}

Certain volatile elements such as thallium, mercury, and antimony are known to form extensive balos surrounding particular types of vein- and massive sulfide-style deposits (c.g., Shaw, 1952; Ikrauddin et al., 1983; Smith and Huston, 1992). Snith (1973) was the first to record $\mathrm{Tl}$ dispersion around a VHMS deposit, later described in detail by Smith and Huston (1992) for the Rosebery deposit, and considered further by Large et al. (2001). Our recent research on several VHMS deposits in Australia has shown that the stratiform Zn-rich deposits, such as Rosebery, Hcllyer, and Thalanga, have significant thallium and antimony halos, whereas the Cu-Au deposits (Western Tharsis, Highway-Reward, and Gossan Hill) show no halos (Figs. 12 and 13).

Both Rosebery and Hellycr exhibit halos extending several hundred meters into the hanging wall in which $\mathrm{Tl}$ and $\mathrm{Sb}$ are greater than $1 \mathrm{ppm}$. Within and close to the ores, values greater than $10 \mathrm{ppm}$ are common, with a systematic decrease outward and stratigraphically upward from the ore lenses (Figs. 12 and 13). The halo at Thalanga is less well developed, extending less than $50 \mathrm{~m}$ into the hanging wall and footwall.

There is a variation in Tl/Sb ratio for the three $\mathrm{Zn}$-rich deposits with significant halos (Fig. 13): Rosebery has a TV/Sb 1, compared to Hellyer, which has a TV/Sb -0.1 , and Thalanga, which has a $\mathrm{Tl} / \mathrm{Sb} \sim 5$. Overall the halo data for all six deposits (Figs. 12 and 13) suggest a relationship between the mean $7 n / C u$ ratio of the orebodies and the extent and magnitude of the TI halo. Western Tharsis, Highway-Reward, and Gossan Hill have $\mathrm{Zn} / \mathrm{Cu}$ ratios $<1$ and no significant $\mathrm{Tl}$ halo, Thalanga with a $\mathrm{Zn} / \mathrm{Cu} \sim 6$ has a weakly developed halo, and Hellyer and Rosebery have $\mathrm{Zn} / \mathrm{Cu}$ ratios $>30$ and well-developed halos. This trend may also be extendcd to include the HYC SEDEX deposit, northern Australia. with a $\mathrm{Zn} / \mathrm{Cu}>50$, and a 


\section{a ROSEBERY}

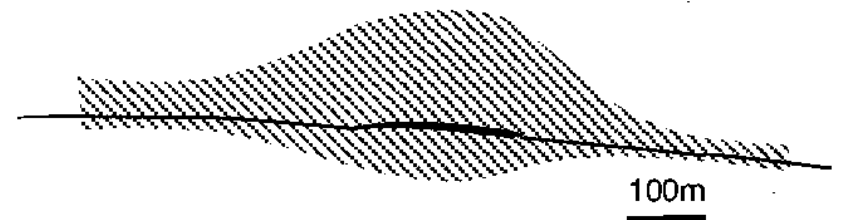

b HELLYER

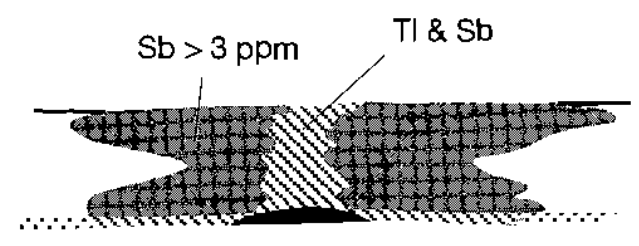

no data in footwall $200 \mathrm{~m}$

\section{c THALANGA}
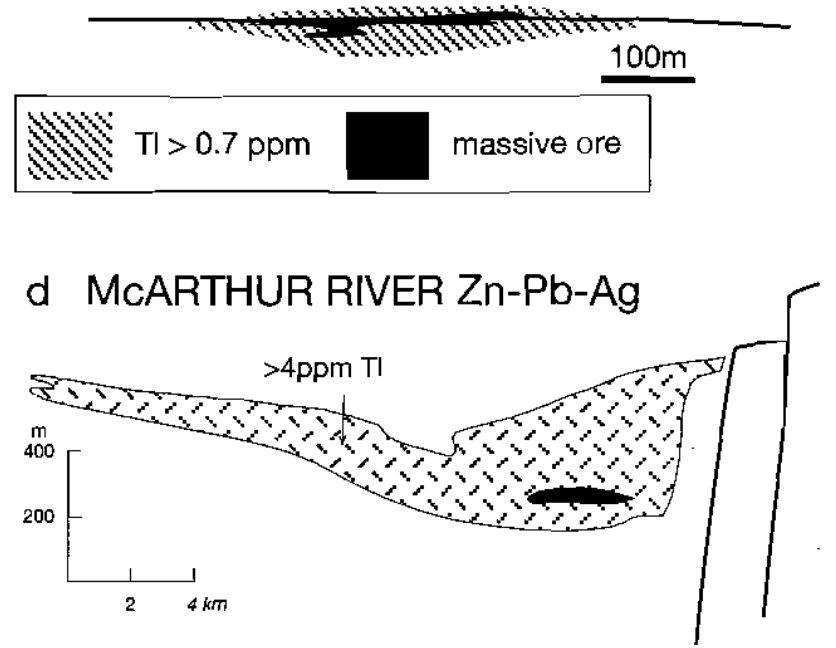

F]G. I2. Extent of thallium halos associated with three zinc-rich VHMS deposits: Rosebery, Hellyer, and Thalanga compared to the McArthur River SEDEX Zu1-Pb-Ag deposit (Large et al., 2000). Note the scale change for McAithur River, where the balo extends for over $20 \mathrm{~km}$ compared to the VHMS deposits, where the halos exteud for less than $1 \mathrm{~km}$ beyond the ore zones.

Tl halo which extends hundreds of meters into the hanging wall and tens of kilometers along strike (Fig. 12d; Large et al., 2000). The lack of $\mathrm{Tl}$ in the Cu-rich ores and their associated alteration halos may relate to their higher temperature of formation. $\mathrm{Tl}$ and $\mathrm{Sb}$ tend to concentrate in the lower temperature $\mathrm{Zn}$-rich systems but are probably too soluble for precipitation in the higher temperature copper-rich systems.

\section{Isotope discrimination and vectors}

Previous studies (e.g., Green et al., 1983; Cathles, 1993; Taylor et al., 2000) have demonstrated the use of whole-rock oxygen isotopes to define hydrothermal fluid/rock interaction and provide vectors to massive sulfide ores im volcanic successions. Research in the Mount Read Volcanics has confirmed the value of whole-rock oxygen isotopes in exploration and also hightighted the potential use of carbon and sulfur isotopes (Solomon et al., 1988; Green and Taheri, 1992; Callaghan, 2001). Lead isotopes have been shown to be a discriminant for synvolcanic versus epigenetic mineralization styles in the belt (Gulson and Porritt, 1987). However, case studies, the fonndation of ore vectors, are not well advanced for the isotopic systems in comparison to trace elements.

Altered volcanics beneath the stratiform $\mathrm{Zn}$-rich deposits display low $\delta^{18} \mathrm{O}$ values (6.5-10\%; Green and Taheri, 1992), and these extend beyond the obvious $\mathrm{Na}$ depletion and $\mathrm{An}-$ $\mathrm{Cu}-\mathrm{Pb}-\mathrm{Zn}$ enrichment of the visible alteration (e.g., Que River; Stolz and Large, 1992). This is typical of VHMS mineralization (e.g., Green et al., 1983; Cathles, 1993). Valnes higher than general footwall background occur within $500 \mathrm{~m}$ of the visible edge of alteration, forming a $900-\mathrm{m}$-wide zone at Hellyer with $\delta^{18} \mathrm{O}=12.0$ to $13.8 \mathrm{per}$ mil and a 150 -m-wide zone with $\delta^{18} \mathrm{O}=14.0$ to 15.6 per mil,100 $\mathrm{m}$ beyond visible alteration at Hercules (Green and Taheri, 1992). Low-grade pyritic mineralization does not display values below background (Green and Taheri, 1992). Miller et al. (2001) outline and apply a method for the conversion of $\delta^{18} \mathrm{O}$ values in the Thalanga Range, Mount Windsor subprovince, to a pseudotemperature profile. using XRD-determined mimeral abundances and assumed values for the starting isotopic compositions of reacting water and rock. This provides a genetic basis for isotope vector interpretation but relies on (1) the accuracy of the assumed valnes, (2) a lack of isotopic resetting during later events, and (3) mimimal influence of inherited oxygen during water-rock reaction.

Sulfur isotope vectors have only been stndied at Rosebery, Hellyer, and, to a limited extent, Que River. By comparison, the sulfur isotope composition of the ores and stringer zone. sulfides in most districts is very well known (e.g., Green et al., 1981; Solomon et al., 1988). The overall $\delta^{34} \mathrm{~S}$ composition for mineral prospects has been proposed to be an economic discriminant for Cambrian deposits (Green and Taheri, 1992). For instance, economic stratiform mineralization in the Mount Read Volcanics has $\delta^{34} \mathrm{~S}>6$ per mil and commonly in the range of 8 to 12 per mil, probably reflecting the mixing of reduced Cambrian seawater sulfate $\left(\delta^{34} S \sim 30 \%\right.$; Claypool et al., 1980) with leached rock sulfur. Strata-bound pyrite with $\delta^{34} \mathrm{~S}<5$ per mil, such as the Boco prospect, is suggested to have formed at $<200^{\circ} \mathrm{C}$, which would prevent both sulfate reduction and base metal leaching (Solomon et al., 1998; Green and Taheri, 1992). However, some mineralization in the Mount Read Volcanics, with $\delta^{34} S<5$ per mil has recently been shown to relate to $\mathrm{Au}-\mathrm{Cu}$-bearing, lighsulfidation fluids, possibly derived from oxidized synvolcanic granites (e.g., Boda, 1991; Huston and Kamprad, 2001). This is an alternative explanation for the low $\delta^{34} S$ valnes, and thus the $\delta^{34} \mathrm{~S}$ discriminant requires modification to incorporate mineralogy.

The sulfur isotope composition of disseminated Fe sulfide in the footwall is emerging as a useful vector to the stratiform Zn-rich ores. Although the footwall stringer veins and disseminations have $\delta^{34} \mathrm{~S}$ values similar to overlying ore, zones of high $\delta^{34} S$ values occur lateral to the main footwall alteration at the three largest Zn-rich deposits in the Mount Read Volcanics. At Hellyer, Jack (1989) and Gemmell and Large (1993) found $\delta^{34} \mathrm{~S}$ values of 11.9 to 40.7 per mil (avg of 


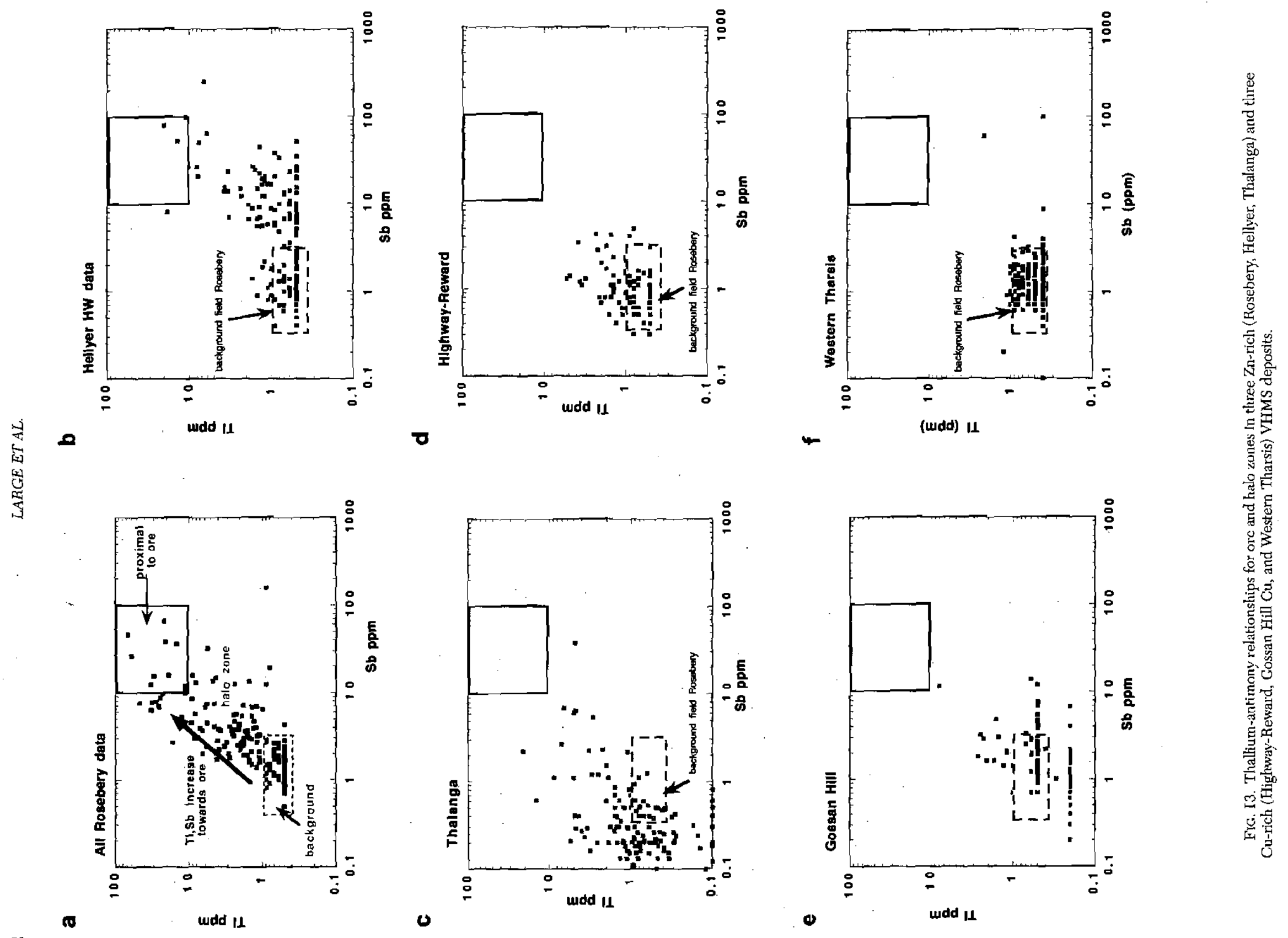


$25.0 \%$ ) in coarse pyrite up to 200 in from the central intense alteration. Similar eurichment has been discovered at Rosebery but is confined to a distinct, tabular 70-m-thick zone $\sim 100 \mathrm{~m}$ from the ore that extends up to $500 \mathrm{~m}$ away from the hydrothermal vent (Davidson et al., 2000). These ${ }^{34}$ S-enriched zones approach and even exceed the isotopic composition of Cambrian seawater sulfate and probably formed by partial in situ seawater sulfate reduction. The values require that sulfate reduction occurred under closed or partly closed conditions that must have differed markedly from those of the main hydrothermal upflow stringer zones. Their precise relationship to associated whole-rock oxygen isotope values has not been established. They have the potential to significantly expand the isotopic halo of large systems and are predicted to be more tabular in porous volcaniclastic units (e.g., Rosebery) than in lavas (e.g., Hellyer, Que River). We speculate that similar zones may occur in other VHMS deposits but have not been detected because few studies have examined the isotopic composition of sulfides lateral to footwall vents, and such sulfides are fine grained requiring bulk sulfur dissolution or microanalytical techniques, both of which are not commonly applied.

\section{Rare earth element vectors}

The rare earth elements (REE) in Fe-Si-bearing oreequivalent lateral marker beds and footwall alteration have been einployed as vectors in massive sulfide districts (Lottermoser, 1989; Peter and Goodfellow, 1996; Spry et al., in press). To date, the ore-equivalent beds have proven most useful for this purpose, although Huston and Kamprad (2001) show there to be significant REE mobility in the very acid alteration zones of some $\mathrm{Cu}-\mathrm{Au}$ systems, such as Western Tharsis.

The chemistry of $\mathrm{Fe}-\mathrm{Si}$ lateral marker beds such as hematitic cherts can only be used in exploration where such umits are common, as in the Mount Windsor subprovince. The REE composition of hematitic chert was successfully used as an exploration filtering tool by Miller et al. (2001) to discover satellite $\mathrm{Zn}-\mathrm{Pb}$ ore in the Mount Windsor subprovince. Chert bodies above and along strike from the Thalanga $\mathrm{Zn}-\mathrm{Pb}-\mathrm{Cu}$ deposit exhibit strong positive Eu anomalies and LREE enrichment (Duhig et al., 1992). Davidson et al. (2001) show that positive Eu anomalies are not a feature of all hematitic chert bodies in the district, supporting the view that they are a valuable screening tool for exploration. Although some chert bodies developed from fluids that were sufficiently acid to destroy feldspar and mobitize $\mathrm{Eu}^{2+}$, others have some features inherited from seawater, such as negative Ce anomalies, and probably originated from cooler rechargedominated fluids (Davidson et al. 2001). Most examples formed in sitn above diffuse alteration zones or within subsurface alteration zones (Doyle, 1997) and are very different from the extensive ore-equivalent marker beds that characterize other massive sulfide districts, such as the Bathurst district (Peter and Goodfellow, 1996). However, in all of these cases, high concentrations of host-rock REE, whether incorporated clastically or by replacement of wall rock, may mask the hydrothermal REE signature of the marker bed. Clastic REE are commonly held in resistate mineral phases that will survive reaction with most hydrothermal fluids (Davidson, 1998; Spry et al., in press). Consequently, if high concentrations of clastic elements such as $\mathrm{Zr}$, Ti, and $\mathrm{Al}$ are evident, the clastic $\mathrm{REE}$ signal must be quantified before the REE composition of the marker bed can be used as an exploration vector.

\section{Summary on exploration vectors}

Schematic summaries of the mineralogical, lithogeochemical, and isotopic vectors useful for exploration are given for Zn-rich stratiform polymetallic ores in Fignre 14 and for pyritic $\mathrm{Cu}-\mathrm{Au}$ ores in Figure 15. Our recent research indicates that the most useful vectors for $\mathrm{Zn}$-rich ores are $\mathrm{Na}$ depletion; the alteration index (AI); the chlorite-carbonatepyrite index (CCPI); Mn content of carbonate; whole-rock Tl, $\mathrm{Sb}$, and $\mathrm{Ba} / \mathrm{Sr}$ ratio; and $\delta^{34} \mathrm{~S}$ of pyrite and whole-rock $\delta^{18} \mathrm{O}$ (Fig. 14). The most useful vectors for pyritic $\mathrm{Cu}-\mathrm{Au}$ ores are $\mathrm{Na}$ depletion, AI, CCPI, $\mathrm{S} / \mathrm{Na}_{2} \mathrm{O}$ ratio, $\mathrm{Na}$ content of white mica, and Fe content of carbonate (Fig. 15). Insufficient data is available to comment on the usefulness of whole-rock $\delta^{18} \mathrm{O}$ and $\delta^{34} \mathrm{~S}$ pyrite as vectors in the pyritic $\mathrm{Cu}-\mathrm{Au}$ hydrothermal systems.

\section{Conclusions}

The most significant conclusions to emerge from recent research on the nature and alteration of Australian VHMS deposits and their host volcanic rocks include the following:

1. There is a spectrum of sulfide deposits in submarine volcanic successions in Australia, including lens and sheet-style Zn-rich polymetallic deposits, massive and disseminated pyritic Cu-Au deposits, and disseminated strata-bound Auonly deposits.

2. The Zn-rich polymetallic deposits form either on, or just below, the sea floor, whereas the $\mathrm{Cu}-\mathrm{Au}$ and Au-only deposits form subsea floor by replacement of particular volcanic units.

3. The pyrite Cu-Au deposits typically form in felsic volcanic centers dominated by synvolcanic intrusions, whereas the zinc-rich polymetallic deposits form in both felsic and mafic, moderate- to deep-water volcanic successions, dominated by lavas, volcaniclastic facies, and volcanogenic sedimentary facies. The gold-only deposits are confined to shallow-water volcanic sequences.

4. Alteratiou zoned outward from quartz $\rightarrow \mathrm{Mg}-\mathrm{Fe}$ chlorite $\rightarrow$ sericite \pm carbonate is typical of VHMS deposits across the spectrum. Quartz and carbonate alteration is dominant in the gold-only systems, whereas chlorite alteration is commonly developed close to copper-rich ores. Sericite and carbonate alteration zones are well developed in the stratiform zinc-rich ores.

5. Thermodynamic modeling indicates that chlorite-rich alteration is generated by higher temperature $\left(>250^{\circ} \mathrm{C}\right)$ and or less acidic $(\mathrm{pH}>5)$ hydrothermal fluids, whereas sericiterich alteration forms from lower temperature, slightly acidic fluids. Pyrophyllite associated with Cu-Au ores is indicative of strongly acidic fluids $(\mathrm{pH}<4$ ), possibly related to involvement of a magmatic fluid.

6. The variation in morphologies, metal ratios, volcanic environments, and alteration features in Australian volcanichosted ores indicates that a spectrum of deposits may existfrom those that fit the classic VHMS model to those that are hybrids between VHMS porphyry $\mathrm{Cu}$ and VHMS epithermal end members, developed in submarine volcanic successions. 


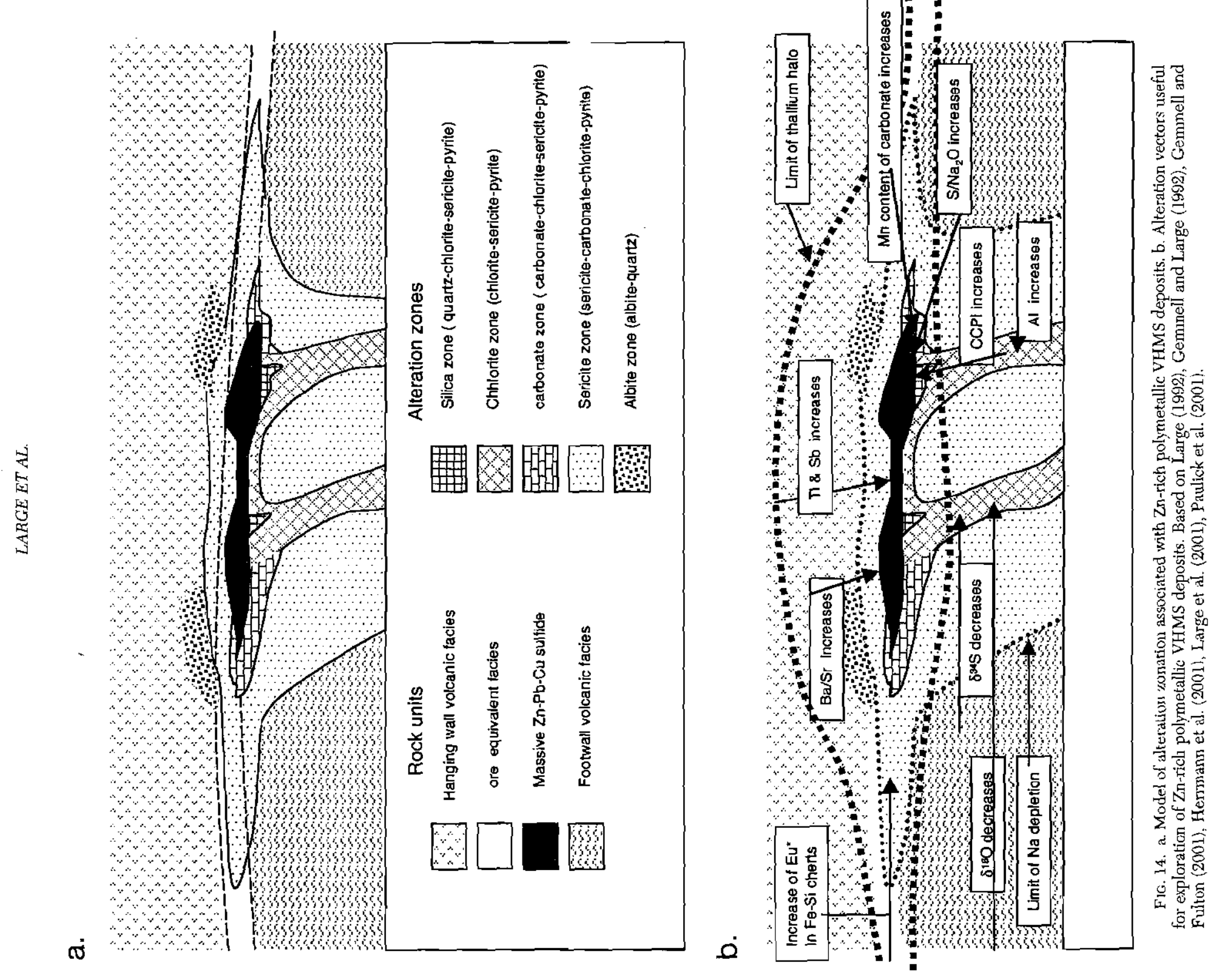

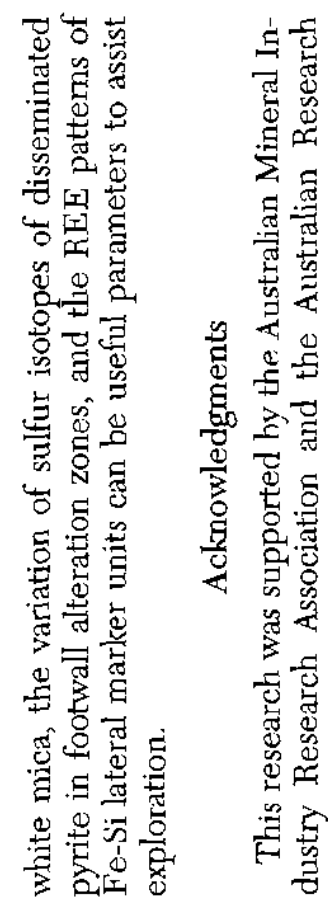

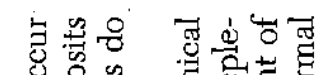

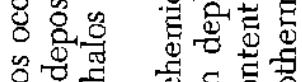
过氙 ह

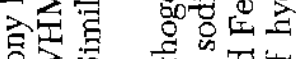

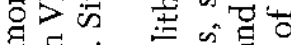

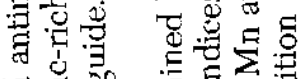

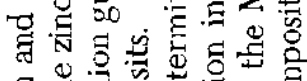

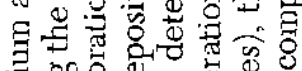

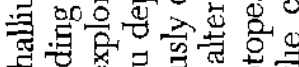
=

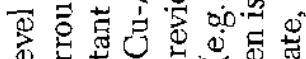
寝

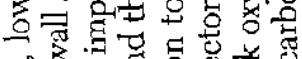
of a .

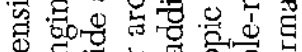

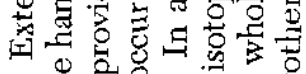

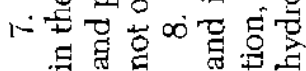




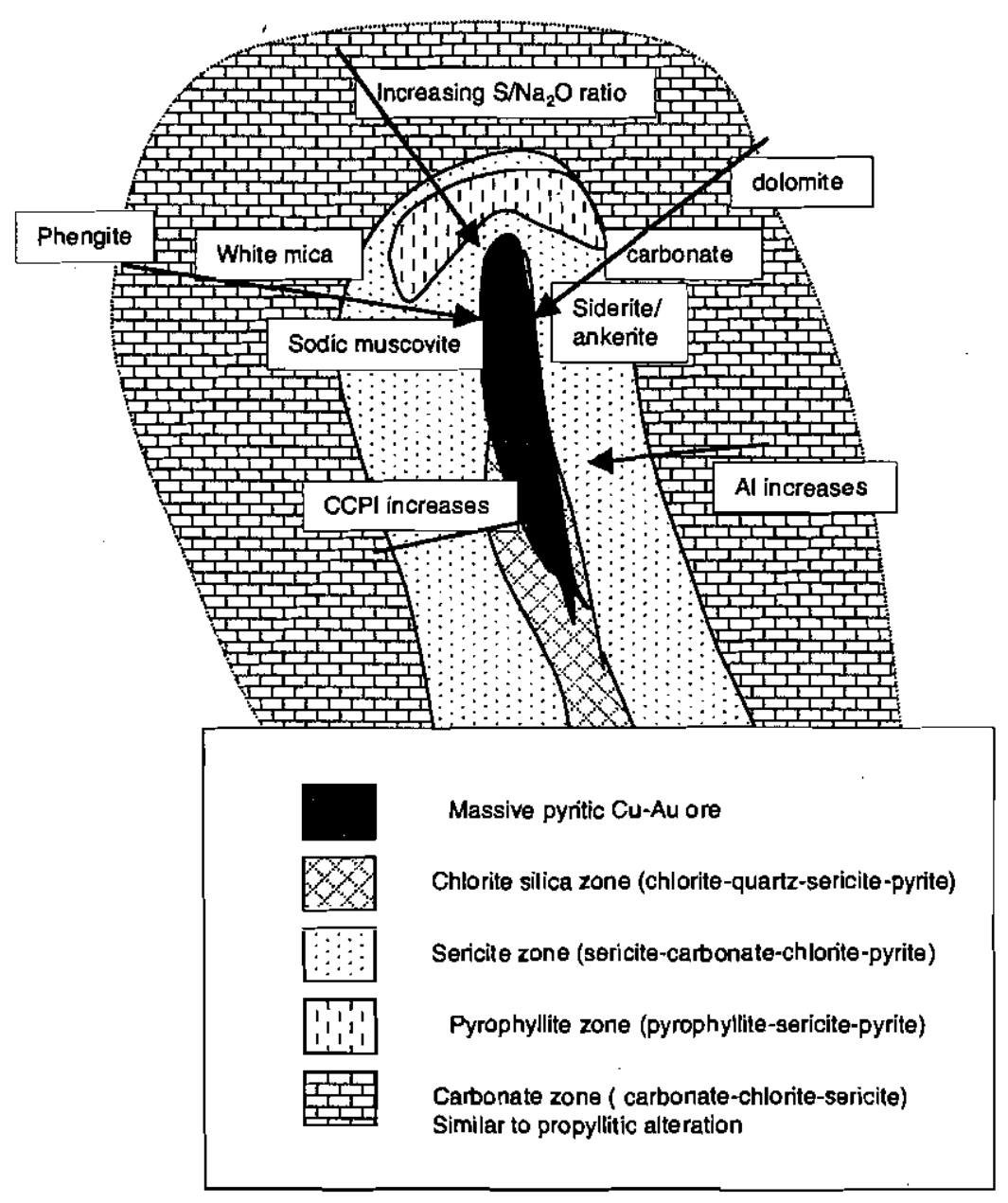

FIG. 15. Model of alteration zonation and key alteration vectors useful for exploration for pyritic Cu-Au VHMS deposits. Based on Doyle (2001), Herrmann et al. (2001), Huston and Kamprad (2001), and Large et al. (2001).

Council SPIRT Scheme. Thanks to many of the contributors to this special issue for providing advanced copies of their papers to enable this review to be completed.

\section{REFERENCES}

Allen, R.L., 1994a, Volcanic facies analysis indicates large pyroclastic eruptions, sill complexes, syn-volcanic grabens, and subtle thrusts in the Cambrian "Central Volcanic Complex" volcanic centre, western Tasmania: Contentious Issnes in Tasmanian Geology Symposium, Geological Society of Australia Tasmanian Division, Extended Abstracts Volume, p. $31-32$.

Allen, R.L., 1994b, Syn-volcanic, snbseafloor replacement model for Rosebery and other massive sulfide ores: Contentious Issnes in Tasmanian Geology Symposium, Geological Society of Australia Tasmanian Division, Extended Abstracts Volnme, p. 89-91.

Alen, R.L., Gifkins, C.C., Large, R.R., and Herrmann, W., 1998, Discrimination of diagenetic, hydrothermal and metamorphic alteration: Hobart, Tasmania, University of Tasmania, CODES-Anstralian Mineral Indnstry Research Association (AMIRA) project P439, Unpnblished final report, p. 93-119.

Arnold, G.O. and Sillitoe, R.H., 1989, Mt Morgan gold-copper deposit Queensland, Australia: Evidence for an intrnsion-related replacement origin: ECONOMIC GEOLOGY, v. 84, p. 1805-1816.
Barrett, T.J., and MacLean, W.H., 1991, Chemical, mass, and oxygen isotope changes during extreme hydrothermal alteration of an Archean rhyolite, Noranda, Quebec: ECONOMtC GEOLOGY, v. 86, p. 406-414.

-1994, Mass changes in hydrothermal alteration zones nssociated with VMS deposits of the Noranda area: Exploration and Mining Geology, v. 3, p. 131-160.

Barrett, T.J., Cattalani, S., and MacLean, W.H., 1993, Volcanic lithogeochemistry and alteration at the Delbridge massive sulfide deposit, Noranda, Quebec: Journal of Geochemical Exploration, v. 48, p. 135-173.

Barrett, T.J., MacLean, W.H., and Tennant, S.C., 2001, Volcarric seqnence and alteration at the Parys Monntain volcanic-hosted massive snlfide deposit, Wales, United Kingdom: Applications of immobile element hithogeochemistry: EGONOMIC GEOLOGY, v. 96, p. 1279-1305.

Beckton, J., 1999, Gold distribution within the Zone 96 gold deposit, western Tasmania: Inflnence of protolith and structural remobilisation: Unpublished Master's thesis in Economic Geology, Hobart, Tasmania, University of Tasmania, $133 \mathrm{p}$.

Berry, R.F., Hnston, D.L., Stolz, A.J., Hill, A.P., Beams, S.D., Knronen, U., and Taube, A., 1992, Stratigraphy, structure, and volcanic-hosted mineralization of the Mount Windsor subprovince, North Queensland, Australia: ECONOMIC GEOLOGY, v. 87, p. 739-763.

Binns, R.A., and Scott, S.D., 1993, Actively forming polymetallic snlfide deposits associated with felsic volcarric rocks in the eastern Manns back-arc basin, Papua New Gninea: ECONOMIC Geolocy, v. 88, p. 2222-2232. 
Boda, S.P., 1991, The geology, structural setting and genesis of the Chester mime, vorthwest Tasmnaia: Unpublished Honors thesis, Canberra, ACT, Australian Nalioual Uuiversity, $111 \mathrm{p}$.

Braithwaite, R.L., 1974, The geology and origin of the Rosebery Ore Deposit, Tasmania: ECONOMiC GeolOCY, v. 69, p. 1086-1101.

Callaghan, T., 1998, Geology and alteration of the Mount Julia deposit, Henty gold mine, Tasmania: Unpublished Master's thesis iu Economic Geology, Hobart, Tasmauia, Trniversity of Tasmania, $78 \mathrm{p}$.

-2001 , Geology and host-rock alteration of the Henty and Mount Julia gold deposits, Western Tasmania: Economic GEoLogy, v. 96, p. 1073-1088.

Cathles, L.M, 1993, Oxygen isotope alteration in the Noranda miniug district, Abitibi Greenstone belt, Quebec: EconomIC GEoloGy, v. 88, p. 1483-1511.

Claypool, G.E., Holser, W.T., Kaplau, I.K., Sakai, H., and Zak I., I980, The age curves of sulfur and oxygen isotopes in marine sulfate and their mutual iuterpretation: Chemical Geology, v. 28, p. I99-260.

Corbett, K.D., 1992, Stratigraphic-volcanic setting of massive sulfide deposits in the Cambrian Mouut Read Volcamics, Tasmania: ECONOMIC GEOLOCY, v. 87, p. 564586.

_ 2001. New mapping and interpretations of the Mount Lyell miuing district, Tasmania-a large hybrid $\mathrm{Cu}-\mathrm{Au}$ system with an exhalative $\mathrm{Pb}-\mathrm{An}$ top: Economic Crolocr, v. 96, p. 1089-1122.

Corbett, K.D., and Komyshan, P., 1989, Geology of the Hellyer-Mt Charter area: Tasmania Department of Miues, Mount Read Volcanics Project Geology Report 1, 48 p.

Cox, S.F., 1981, The stratigraphic and structural setting of the Mount Lyell volcanic-hosted sulfide deposits: ECONOMIC GEOLOGY, v. 76, p. 231-245.

Crawford, A.J., Corbett K.D., and Everard, Y.L., 1992, Geochemistry of the Cambrian-rich volcanic-hosted massive sulfide Mount Read Volcanics, Tasmanid, and some tectonic implications: ECONOMIC CEOLOGY, v. 87, p. 597-619.

Davidson G.J., 1998, Application of silica iron deposit geochemistry to exploratiou for VHMS deposits in the Mount Windsor volcanic belt: Hobart, University of Tusmania, CODES-Australian Mineral ludustry Research Associatiou (AMIRA) project P439, Unpublished fiual report, p. 135-188.

Davidsou, G.J., Garven. G., Kitto, P., aud Berry, R.F., 2000, Geochemically discrete fluid bodies formed by convectiou at the heated edge of porous scatloor aquifer [abs.]: Beyond 2000: New Frontiers iu lsotope Geoscience, Lorne, 2000, Ahstracts and Proceedings, p. 39-40

Davidsou, G.J., Stolz, A.J., and Eggins, S.M., 2001, Geochemical anatomy of silica iron exhahites: Evidence for hydrothermal oxyaniou cycling in respouse to vent fluid redox aud thermal cvolution (Mt. Wudsor subprovince, Australia): ECONOMIC GEOLOGY, v. 96, p. 1201-1226.

Doyle M., 1997, A Cambro-Ordovician volcanic succession hosting massive suffide mincralisation: Mount Windsor subprovince, Qld: Unpublished Ph.D thesis, Hobart, Tasmania, University of Tasmania, $305 \mathrm{p}$.

Doyle, M.G., 1990, The geology of the Jukes Proprietary prospect, Mount Read Volcanics: Unpublished Honors thesis, Hobart, Tasmania, University of Tasmania, $114 \mathrm{p}$.

-2001, Volcanic influences on hydrothermal and diagenetic alteration: Evidence from the Highway-Reward deposit, Mount Windsor subprovince, Austrahia: ECONOMIC GEOLOGY, v. 96, p. 1133-1148.

Doyle, M.G., and H.rston, D.L., 1999, The subsca-floor replatement origin of the Ordoviciau Highway-Reward volcanic-associated massive sulfide deposit, Mount Windsor subprovince, Australia: ECoNomlC GEOLOGY, v. 94, p. $825-813$.

Doyle, M.G., and McPhie, J., 2000, Facies architecture of a silicic intrusioudominated volcanic centre at Highway-Reward, Queensland, Australia: Journal of Vocauology and Geothermal Research, v. 99, p. 79-96.

Duhig, N.C., Stolz, J., Davidson, G.J., and Large, R.R., 1992, Cambrian microbial and silica gel textures preserved in silica iron exhalites of the Mouut Windsor volcanic belt, Australia: Their petrography, geochemistry, and ongiu: ECONOMIC GEOLOGr, v. 87, p. $764-784$.

Eastoe. C.J., Solmmn, M., and Walshe, Y.L., 1987, District-scale alteratiou associated with inassive sulfide deposits in the Mount Read Volcanics, western Tasmania: ECONOMIC GEOLOCY, v. 82, p. 1239-1258.

Eldridge, C.S., Barton, P.B., Jr., and Olımoto, H., 1983, Mineral textures aud their bearing on formation of the Kuroko orebodies: ECONOMIC GEOLOCY Monograph 5, p. 241-281.

Franklin, J.M., 1995, Volcanic-associated massive sulfide base metals: Geological Survey of Canada, Geology of Canada, no. 8, p. 158-183.

Franklin. J.M., Kasarda, J., and Poulsen, K.H., 1975, Petrology and chemistry of the alteration zone of the Mattabi massive sulfide deposit: EcoNomIC GEOLOGY, v. 70, p. 63-79.
Franklin, J.M., Sangster, D.F, and Lydon, J.W., 1981, Volcauic-associated massive sulfide deposits: ECONOMIC CEOLOGY $75^{\text {th }}$ ANNIVERSARY VOlume, p. $485-627$.

Galley, A.G., 1995, Target vectoring using hthogeochemistry: Applications to the exploration for volcanic hosted massive sulfide deposits: CIM Bulletin, v. 88 , no. 990 , p. 15-25.

Gemmell, J.B., and Fulton, R., 2001, Gcology, genesis, and exploration implications of the footwall and hanging-wall alteration associated with the Hellyer volcauric-hosted massive sulfide deposit, Tasmama, Australia: EcoNOMIC GEOLOGY, v. 96, p. I003-I035.

Gemmell, J.B., and Large, R.R., 1992, Stringer system and alteration zones underlying the Hellyer volcauogenic massive sulfide deposit, Tasmania, Australia: F.conomic Georogy, 87, p. 620-649.

-1993, Evolution of a VHMS hydrotherinal system, Hellyer deposit, Tasmania, Australin: Sulfur isotope evidence: Resource Geology Special Issue I7, p. 108-II9.

Gifkins, C.C., and Allen, R.L., 2001, Textural and chenical characteristics of diagenetic and hydrothermal alteration in glassy volcanic rocks: Examples from the Mount Kead Volcauics, Tasmania: Economic Geolocy, v. 96, p. 973-I002.

Goldfarb, M.S., Couverse, D.R.. Holland, H.D., and Edmond, J.M., I983, The genesis of hot spring deposits on the East Pacific Rise, $21^{\circ} \mathrm{N}$ : EcoNOMIC GEOLOGY MONOGRAPH 5, p. I84-197.

Grant, J.A., T986, The Isocou diagram: A simple solution to Gresens' equation for metasomatic alteration: Economic GEoLocr, v. 81, p. 1976-1982. Green, G.R., and Taheri, J., I992, Stable isotopes and geochemistry as exploration indicators: Geolugical Survey of Tasmania Bulletiu, v. 70, p. 84-91.

Green, G.R., Solomon, M., aud Walshe, J.L., I981, The formation of the volcanic-hosted massive sulfide ore deposit at Rosebery, Tasmania: Economir GEOLOGY, v. 76, p. 304338.

Gregory, P.W., Hartley, J.S., and Wills, J.A., I990, Thalanga zinc-lead-coppersilver deposit: Australasian Institute of Mining and Metallurgy Mouograph I4, p. I527-1537.

Greseus, R.L., 1967, Composition-volume relationship of metasomatism: Chemical Geology, v. 2, p. 47-65.

Gulsou, B.L., and Porritt, P.M., I987, Base metal exploration of the Mount Read Volcanics, westem Tasmania: Pt. II. Lead isotope signatures and genetic implications: ECONOMs GEOLOGY, v. 82, p. 291-307.

Halley, S.W., and Roberts, R.H., 1997, Henty: A shallow-water gold-rich volcauogenic massive sulfide deposit in western Tasmania: ECONOMIC GrolOGY, v. 92 , p. $438-447$.

Henderson, R.A.,1986, Geology of the Mount Windsor subprovince-a lower Palaeozoic volcano-sedimentary terrane in the northern Tasman orogenic zoue: Australian Journal of Earth Sciences, v. 33, p. 343-364.

Herrmann, W., and Hill, A.P., 2001, The origiu of chlorite-tremolite-carbonate rocks associated with the Thalanga volcanic-liosted massive sulfide deposit, North Queensland, Australia: ECONOMIC GEOLOCx, v. 96, p. 1149-1I73.

Herrmann, W., Blake, M., Doyle, M., Hustou, D., Kamprod, J., Merry, N., and Pontual, S., 200I, Short wavelength infrared (SWTR) spectral analysis of hydrothermal alteration zones associated with base metal sulfide deposits at Rosebery and Western Tharsis, Tasmauia, and Highway-Reward, Queensland; ECONOM]C GEOLOGY, v. 96, p. 939-955.

Hill, A.P., 1996, Structure, volcanic setting, hydrothermal alteratiou and genesis of the Thalanga massive sulphide deposit: Upuhlished Ph.D. thesis, Hobart, Tasmania, University of Tasmania, $404 \mathrm{p}$.

Hunus, S.R., I987, Mineralisation of the Lake Selina prospect: Unpublished Master's thesis, Hobart, Tasmatia, Uuiversity of Tasinania, $126 \mathrm{p}$.

Huston, D.L., and Kamprad, J., 2001, Zonation of alteration facies at Western Tharsis: Implications for the genesis of $\mathrm{Cu}-\mathrm{Au}$ deposits in the Mount Lyell field, westeru Tasmania: ECoNomIC GEOLOCY, v. 96, p. 1123-1132.

Iklamuddin, M., Asmeron, Y., Nordstrom, P.M., Kinart, K.P., Martin, W.M., Digby, S.J.M., Elder, D.D., Nijak, W.F. and Afemari, A.A., 1983, Thallinm: a potential guide to mineral deposits: Jourual of Geochemical Exploration, v. 19 , p. $465-490$.

Ishikawa, Y., Sawaguchi, T., Iwaya, S., and Horiuchi, M., 1976, Dclineation of prospecting targets for Kuroko deposits based on modes of volcanism of underlyiug dacite and alteration halos: Mining Geology, v. 26, p. 105-117 (in Japanese with Euglish abs.).

Jack, D., 1989. Hellyer host rock alteration: Uupublished M.Sc. thesis, Hobart, Tasmania, Lniversity of Tasmania, $182 \mathrm{p}$.

Jones, A.T., 1993, The geology, geochemistry and structure of the Mount Darwin-South Darwin Peak area, western Tasmania: Uupublished Honors thesis, Hobart, Tasmania, University of Tasmania, $120 \mathrm{p}$. 
Khin Zaw, 1991, The effect of Devonian metamorpłism and metasomatism on the mineralogy and geochenistry of the Cambrian VMS deposits in the Rosebery-Hercnles district, westem Tasmania: Unpublished Ph.D. thesis, Hobart, Tasmania, University of Tasmania, 302 p.

Khin Zaw, and Large, R.R., 1992, The precions inetal-rich Sonth Hercules mineralization, western Tasmania: A possible snbsea-floor replacement volcaric-hosted massive snlfide deposit: ECONOMIC GEOLOGY, v. 87, p. $931-952$.

Khin Zaw, Gemmell, J.B., Large, R.R., Mernagh, T., and Ryan, C.G., 1996, Microthermometry and geochemistry of fluid inclnsions in the stringer zone, Hellyer VHMS deposit, Tasmania, Australia: Ore Geology Reviews, v. 10 , p. $251-278$

Khin Zaw, Huston, D.L., Gemmell, J.B., Hnnns, S.R., Large, R.R., Ryan, C.G., and Mernagh, T.P., im press, Microthermometry and geochemistry of ore fluids bearing on the genesis of VHMS deposits: Water depth and source of metals [abs.]: ECROFl Conference, 16th, Portugal, 2001, Abstracts.

Khin Zaw, Huston, D.L., and Large, R.R., 1999, A ehemical model for the Devonian remobilisation process in the Cambrian volcanic-hosted massive sulfide Rosebery deposit, western Tasmarria: ECONOMIC GEOLOCY, v. 94, p. 529-546.

Khin Zaw, Huston, D.L., Gemmell, J.B., Hunns, S.R., Large, R.R., Ryan, C.G., and Mernagh, T.P., 2001, Microthermometry and geochemistry of ore fluids bearing on the genesis of VHMS deposits: Water depth and source of metals: ECROFI Conference, European Current Research on Fluid Inclnsions, 16th, Porto, Portngal, Abstracts, p. $463-466$.

Large, C.P., 1995, Stratigraphy and alteration of the Tyndall Group at Henty: Unpublished B.Sc. Honors thesis, Hobart, Tasmania, University of Tasmauia, 119 p.

Large, R.R., 1977, Chernical evolntion and zonation of massive sulfide deposits in volcanic terrains: ECONOMIC GEOLOCY, v. 72, p. $549-572$.

1992 , Austratian volcanic-hosted massive sulfide deposits: Featnres, styles, and genetic models: ECONOMIC GEOLOCY, v. 87, p. 471-512.

-19.97 , Variability is the key to understanding the genesis of Anstralian Palaeozoic volcanic hosted massive sulfide deposits [abs.]: SEG Neves Corvo Field Conference, Lisbon, May 11-14, 1997, Abstracts and Program, p. 54.

Large, R.R., Doyle, M., Raymond, O., Cooke, D., Jones, A., and Heasman, L., 1996, Evalnation of the role of Cambrian granites in the genesis of world class VHMS deposits in Tasmania: Ore Geology Reviews, v. 10, p. 215-230.

Large, R.R., Bull, S.W, and McGoldrick, P.J., 2000, Lithogeochemical halos and geochemical vectors to stratiform sediment hosted $\mathrm{Zn}-\mathrm{Pb}-\mathrm{Ag}$ deposits, Part 2: HYC Deposit, Northern Territory. Journal of Geochemical Exploration, v. 64, 1-2, p. 105-126.

Large, R.R., Allen, R.L., Blake, M.D., and Hermann, W. 200la, Hydrothermal alteration and volatile element halos for the Rosebery $\mathbf{K}$ lens volcanic-hosted massive sulfide deposit, western Tasmania: ECONOMIC GEOLOCY, v. 96, p. 1055-1072.

Large, R.R., Gemmell, J.B.: Paulick, H., and Huston, D.L., 200lb, The alteration box plot: A simple approach to understanding the relationship between alteration mineralogy and lithogeochemistry associated with volcanichosted massive sulfide deposits: ECONOMIC GEOLOGY, v. 96, p. 957-971.

Lentz, D.R., Hall, D.C., and Hoy, L.D., 1997, Chemostratigraphic, alteration and oxygen isotope trends in a profile through the stratigraphic sequence hosting the Heath Steele B zone massive sulfide deposit, New Brunswick: Canadian Mineralogist, v. 35, p. 841-874.

Lottermoser, B., 1989, Rare earth element study of exhalites within the Willyama Snperoroup, Broken Hil] block, Australia: Mineralium Deposita, v. 24, p. 92-99.

Luff, W., Goodfellow, W.D., and Juras, S.J., 1992, Evidence for a feeder pipe and associated alteration at the Brunswick no. 12 massive snlfide deposit: Exploration and Mining Geology, v. 1, p. 167-185.

Lydon, J.W., 1984, Solne observations on the mineralogical and chemical zonation patterns of volcanogenic sulphide deposits of Cyprus: Geological Survey of Canada Paper 84-1A, p. 6l1-616.

_ 1988 , Volcanogenic massive sulphide deposits, Part 2: Genetic models: Geoscience Canada Reprints Series 3, p. 155-182.

Lydon, J.W., and Galley, A., 1986, Cliemical and mineralogical zonation of the Mathati alteration pipe, Cyprus, and its genetic significance, in Gallagher, M.J., Ixer, R.A., Neary, C.R., and Prichard, H.M., eds., Metallogeny of basic and nltrabasic rocks: London, Institute of Mining and Metallogeny, p. 49-68.

MacLean, W.H., and Barrett, T.J., 1993, Lithogeochemical techniqnes using immobile elements: Joumal of Geochemical Exploration, v. 48, p. 109-133.
McArthur, G.J., 1989, Hellyer: Geological Society of Australia Special Pnblication 15, p. $144-148$.

1996, Textural Evolntion of the Hellyer massive snlphide deposit: Unpublished Ph.D. thesis, Hobart, Tasmania, University of Tasmania, $272 \mathrm{p}$. McGoldrick, P.J., and Large, R.R., 1992, Geologic and geochemical controls on gold-rich stringer mineralization in the Que River deposit, Tasmania: ECONOMYC GEOLOGY, v. 8T, p. 667-685.

McPhie, J., and Allen, R.L., 1992, Facies arclintecture of mmeralized snbmarine volcanic seqnences: Cambrian Mount Read Volcanics, western Tasmania: ECONOMIC GEOLOGY, v. 87, p. 587-596.

McPhie, J., Doyle, M., and Allen, R., 1993, Volcanic textures. A gmide to the interpretation of textures in volcanic rocks: Hobart, Tasmania, Centre for Ore Deposit Research, University of Tasmania, Hobart, $198 \mathrm{p}$.

Messenger, P.R., Golding, S.D., and Taube, A., 1997, Volcanic setting of the Mount Morgan Au-Cu deposit, central Queensland: Implications for ore genesis: Geological Society of Australia Special Publication 19, p. 109-127.

Miller, C., Halley, S., Green, G., and Jones, M., 2001, Discovery of the West 45 volcanic-hosted massive sulfide deposit nsing oxygen isotopes and REE geochemistry: ECONOMIC GEOLOGY, v. 96, p. 1227-1237.

Morton, R.L., and Franklin, J.M., 1987, Two-fold classification of Archean volcamic-associated massive sulfide deposits: ECONOMIC GEOLOGX, v. 82, p. 1057-1063.

Ohmoto, H., Mizukami, M., Drumınond, S.E., Eldridge, C.S., PisnthaArnond, V., and Lenagh, T.C., 1983, Chemical processes of Kuroko formation: ECONOMIC GEOLOGY MONOGRAPH 5. p. 570-604.

Paulick, H., 1999, The Thalanga sequence-facies architecture, geochemistry, alteration and metamorphism of felsic volcanics hosting the Thalanga massive suffide deposit: Unpnblished Ph.D. thesis, Hobart, Tasmania, University of Tasmania, $220 \mathrm{p}$.

Panlick, H., and McPlne, J., 1999, Facies architectnre of the felsic lavadominated host seqnence to the Thalanga massive sulfide deposit, Lower Ordovician, northern Queeusland: Australian Jonmal of Earth Sciences, v. 46 , p. $391-405$.

Paulick, H., Henmann, W., and Gemmell, J.B., 2001, Alteration of felsic volcamics hosting the Thalanga massive snlfide deposit, North Qneensland, Australia: Geochemical proximity indicators to ore: ECONOMIC GEOLOGY, v. 96 , p. $1175-1200$.

Perkins, C., and Walshe, J.L., 1993, Geochronology of the Mount Read Volcanics, Tasmania, Australia: EcoNomIC GEOLOGY, v, 88, p. 1176-1197.

Peter, J.M., and Goodfellow, W.D., 1996, Mineralogy, bulk and rare earth element geochemistry of massive snlphide-associated hydrothermal sediments of the Brunswick horizon, Bathurst mining camp, New Brunswick: Canadian Journal of Earth Sciences, v. 33, p. 252-283.

Polya, D.A., Solomon, M., Eastoe, C.J., and Walshe, J.L., 1986, The Murchison Gorge, Tasmania - a possible cross section through a Cambrian massive sulfide system: ECONOM[C GEOLOGY, v. 81, p. 1341-1355.

Poulson, K.H., and Hannington, M.D., 1995, Volcanic-associated massive sulfide gold: Geological Survey of Canada, Geology of Canada, no. 8, p. 183-196. Raymond, O., 1992. Geology and mivieralisation of the sonthern Prince Lyell Deeps, Queenstown, Tasmamia: Unpnblished M.Sc. thesis, Hobart, Tasmania, University of Tasmania, $161 \mathrm{p}$.

Riverin, G., and Hodgson, C. .., 1980, Wall-rock alteration at the Millenbach Cu-Zn mine, Noranda, Qnebec: Economic Geolocr, v. 75, p. 424444.

Roberts, R.G., and Reardon, E.J., 1978, Alteration and ore forming processes at Mattagami Lake mine, Quebec: Canadian Journal of Earth Sciences, v. 15 , p. $1-21$.

Sangster, D.F., 1972, Precambrian volcanogenic massive sulphide deposits in Canada: A review: Geological Snrvey of Canada Paper 72-22, 44 p.

Sato, T., 1973, A chloride complex model for Kuroko mineralisation: Geochemical Journal, v. 7 , p. 245-270.

Schardt, C., Cooke, D.R., Gemmell, J.B., and Large, R.R., 2001, Geochemical modeling of the zoued footwall alteration pipe, Hellyer volcanic-hosted massive sulfide deposit, western Tasmania, Anstralia: ECONOMIC GEOLOCY, v. 96, p. $1037-1054$

Scott, S.D., 1992, Polymetallic sulfide riclies from the deep: Fact or fallacy?, in Hsn, K.J., and Thiede, J., eds., Uses and misuses of the seafloor: New York, NY, John Wiley and Sons, p. 87-115.

Sharpe, R., and Geminell, J.B., 2001, Alteration characteristics of the Archean Golden Grove Formation at the Gossan Hill deposit, Western Australia: Indnration as a focusing mechanism for mineralizing hydrothermal fluids: ECONOMIC GEOLOGy, v. 96, p. 1239-1262.

Shaw, D.M., 1952, The geochemistry of thallium: Geochimica et Cosmochimica Acta, v. 2, p. $118-154$. 
Sillitoe, R.H., Hannington, M.D., and Thompson, J.F.H., I996, High sulfidation deposits in the volcanogenic massive sulfide environment: ECONOMIC GEOLOCY, v. 9I, p. 204-212.

Smith, R.N., 1973, Trace element distributions within some major stratiform orebodies: Unpubhished BSc (Hons) thesis, University of Melbourne, I89 p.

Sinith, R.N., and Fuston, D.L., 1992, Distribution and association of selected trace elements at the Rosebery deposit, Tasmania: Economic GEOLOGY, v. 87, p. 706-719.

Solumon, M., 1976, "Volcanic" massive sulphide deposits and their host rocks-a review and an explanation, in Wolf, K.H., ed., Handbook of stratabound and stratiform ore deposits: II: Regional studies and specific de posits: Ansterdam. Elsevier, 320 p.

Solomon, M., and Groves, D.I., 1994, The geology and origin of Australia's mineral deposits: Monographs in Geology and Geophysics 24, Oxford, Oxford University Press, $951 \mathrm{p}$.

2000 , The geology and origin of Australia's mineral deposits. Reprinted with additional material: Hobart, Tasmania, University of Tasmania, Centre for Ore Depusit Research, and Nedlands, WA, University of Westem Australia, Centre for Global Metallogeny, I002 p.

Solomon, M. and Khin Zaw, 1999, Formation on the sea floor of the Hellyer volcanogenic massive sulfide deposit: Economic GeoLocy, v. 92, p. $686-695$.

Solomon, M., and Walshe, J.L., 1979, The formation of massive sulfide deposits on the sea floor: ECONOMIC GEOLOGY, v. 74, p. 797-813.

Solomon, M., Eastoe, C.I., Walshe, J.L., and Green, G.R., I988, Mineral deposits and sulfrr isotope abundances in the Mount Read Volcanics between Que River and Munit Darwin, Tasmania: ECONOMIC GeOLOGY, v. 83, p. $1307-1328$.

Spry, P.G., Peter, J.M., and Slack J.F., 2000, Meta-exhalites as exploration grrides to ore: Reviews in Economic Geology, v. 11, p. I63-20I.

Stanley, C.R., and Macleisky, H.E., 1994, Lithogeochemical exploration for hydrothermal ore deposit using Pearce element ratio analysis: Geological Association of Canada Short Course Notes, v. 11, p. 19'3-212.

Stolz, J., and Large, R.R., I992, Evaluation of the source-rock control on precions metal grades in volcanic-hosted massive sulfide deposits from westem Tasmania: ECONOMIC GEOLOCY, v. 87, p. 720-738.
Taylor, B.E., Holk, G.J., and Hnston, D.L., 2000, Oxygen isotope mapping and evaluation of palaeo-hydrotherinal systems associated with synvolcanic intrusions and VMS deposits [abs.]: Hobart, Tasmania, University of Tasmania, CODES Special Publication 3, Program and Abstracts, p. 207-208.

Urabe, T., and Scott, S.D., I983, Geochemistry and footwall alteration of the South Bay massive sulfide deposit, northwcsten Ontario, Canadi: Caniatdian Journal of Earth Sciences, v. 20, p. 1862-1879.

Urabe, T., Scott, S.D., and Hattori, K., 1983, A comparison of footwall-rock alteration and geothermal systems beneath some Japanese and Canadian volcanogenic massive sulfide deposits: ECONOMIC GEOLOGY MONOCKAPF 5 , p. $345-364$.

Walshe, J.L., and Solomon, M, 198I, An investigation into the enviroument of formation of the volcanic-hosted Mt. Lyell copper deposits nsing geology, mineralogy, stable isotopes, and a six-component chlorite sohd-solution model: ECONOMIC GFOLOr:Y, v. 76, p. 246-284.

Waters, I.C., and Wallace, D.B., 1992, Volcanology and sedimentology of the host succession to the Hellyer and Que River volcamic-hosted massive sulfide deposits, northwestem Tasmania: Economig Geolocy, v. 87, p. $650-666$.

White, M.J., and McPlize, J., 1996, Stratigraphy and palaeovolcanology of the Cambrian Tyndall Gronp, Mt. Read Volcanics, westorn Tasmania. Austrahian Joumal of Earth Sciences, v. 43, p. 147-159.

- 1997 , A submarine welded ignimhite-crystal-jieh sandstone facies association in the Camhrian Tyndall Group, western Tasmania: $\Lambda$ ustralia. Journal of Volcanology and Geothermal Research, v. 76, p. 277-295.

White, N.C., and Hedenquist, J.W., I995, Epithermal gold deposits: Styles, characteristics, and exploration: Society of Economic Gcologists Newsletter 23, p. 9-I3.

Wyman, W.F., 2000, Cambrian granite-related hydrothermal alteration and Cu-Au mineralisation in the southern Mount Read Volcanics, westcm Tasmania, Australia: Unpnblished Ph.D. thesis, Hobart, Tasmania, University of Tasmania, $416 \mathrm{p}$. 